Prepared in cooperation with U.S. Environmental Protection Agency

Region 4 Superfund Section

\title{
Geophysical Logging and Geologic Mapping Data in the Vicinity of the GMH Electronics Superfund Site near Roxboro, North Carolina
}

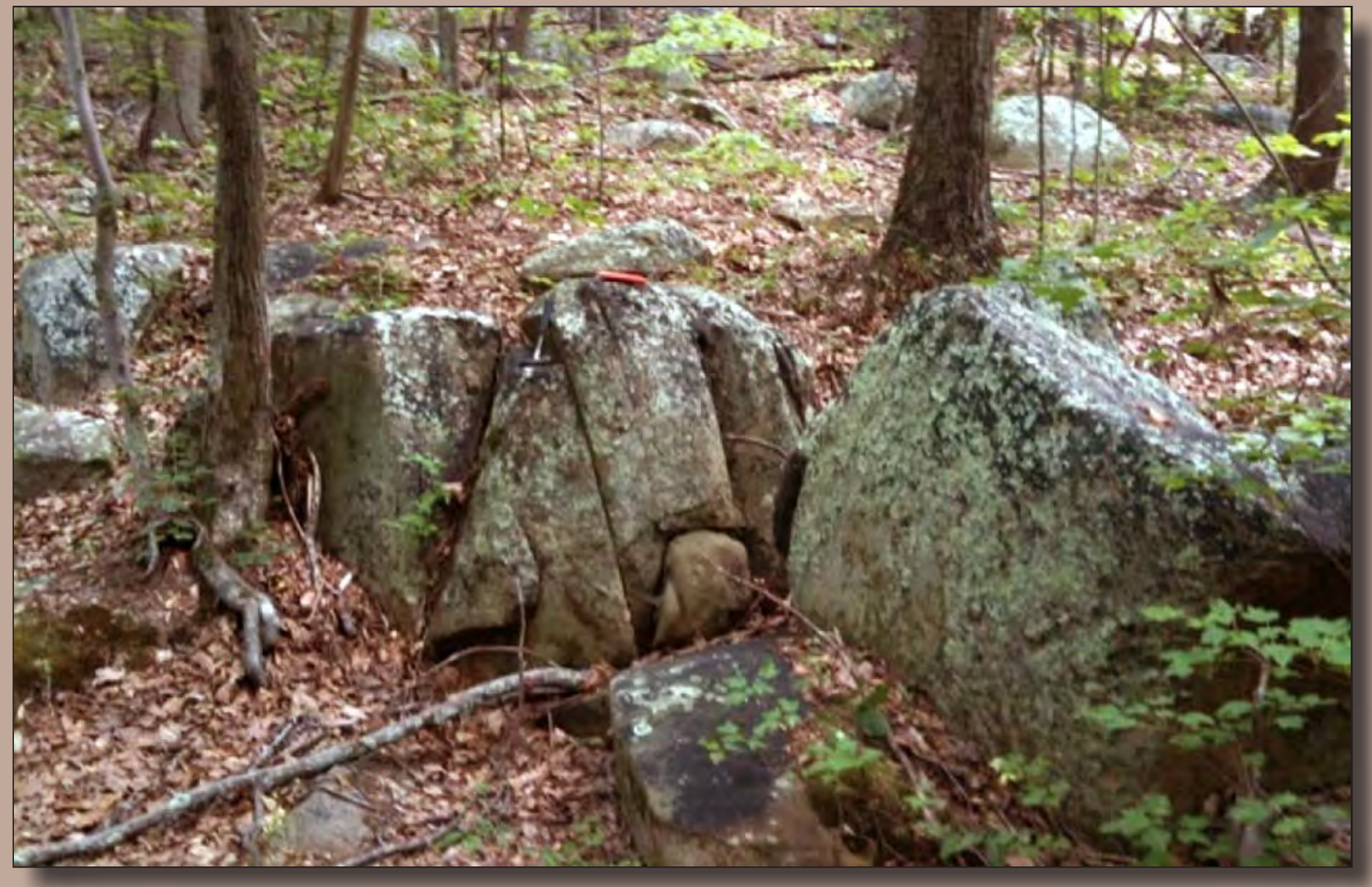

Data Series 762

U.S. Department of the Interior

U.S. Geological Survey 
Cover: Typical granite boulder field near the GMH Electronics Superfund site, Person County, North Carolina. Photograph by Timothy W. Clark, private contractor. 


\section{Geophysical Logging and Geologic Mapping Data in the Vicinity of the GMH Electronics Superfund Site near Roxboro, North Carolina}

By Melinda J. Chapman, Timothy W. Clark, and John H. Williams

Prepared in cooperation with the U.S. Environmental Protection Agency

Region 4 Superfund Section

Data Series 762 


\title{
U.S. Department of the Interior SALLY JEWELL, Secretary
}

\section{U.S. Geological Survey Suzette M Kimball, Acting Director}

\author{
U.S. Geological Survey, Reston, Virginia: 2013
}

For more information on the USGS - the Federal source for science about the Earth, its natural and living resources, natural hazards, and the environment, visit http://www.usgs.gov or call 1-888-ASK-USGS.

For an overview of USGS information products, including maps, imagery, and publications, visit http://WwW.usgs.gov/pubprod

To order this and other USGS information products, visit http://store.usgs.gov

Any use of trade, product, or firm names is for descriptive purposes only and does not imply endorsement by the U.S. Government.

Although this report is in the public domain, permission must be secured from the individual copyright owners to reproduce any copyrighted materials contained within this report.

Suggested citation:

Chapman, M.J., Clark, T.W., and Williams, J.H., 2013, Geophysical logging and geologic mapping data in the vicinity of the GMH Electronics Superfund site near Roxboro, North Carolina: U.S. Geological Survey Data Series 762, 35 p., at $h t t p: / / p u b s . u s g s . g o v / d s / 762 /$. 


\section{Acknowledgments}

The authors would like to thank Harold Kelly and Justin Smith of the Person County Health

Department for their assistance with well logging logistics, the collection of downhole camera logs, and support throughout the project.

We appreciate the assistance of Scott Caldwell, Erik Staub, and Kristen McSwain of the USGS North Carolina Water Science Center in the collection of geophysical logs and the passive-

diffusion-bag samples. Appreciation also is extended to USGS report colleague reviewers Brad Huffman and Eve Kuniansky. 



\section{Contents}

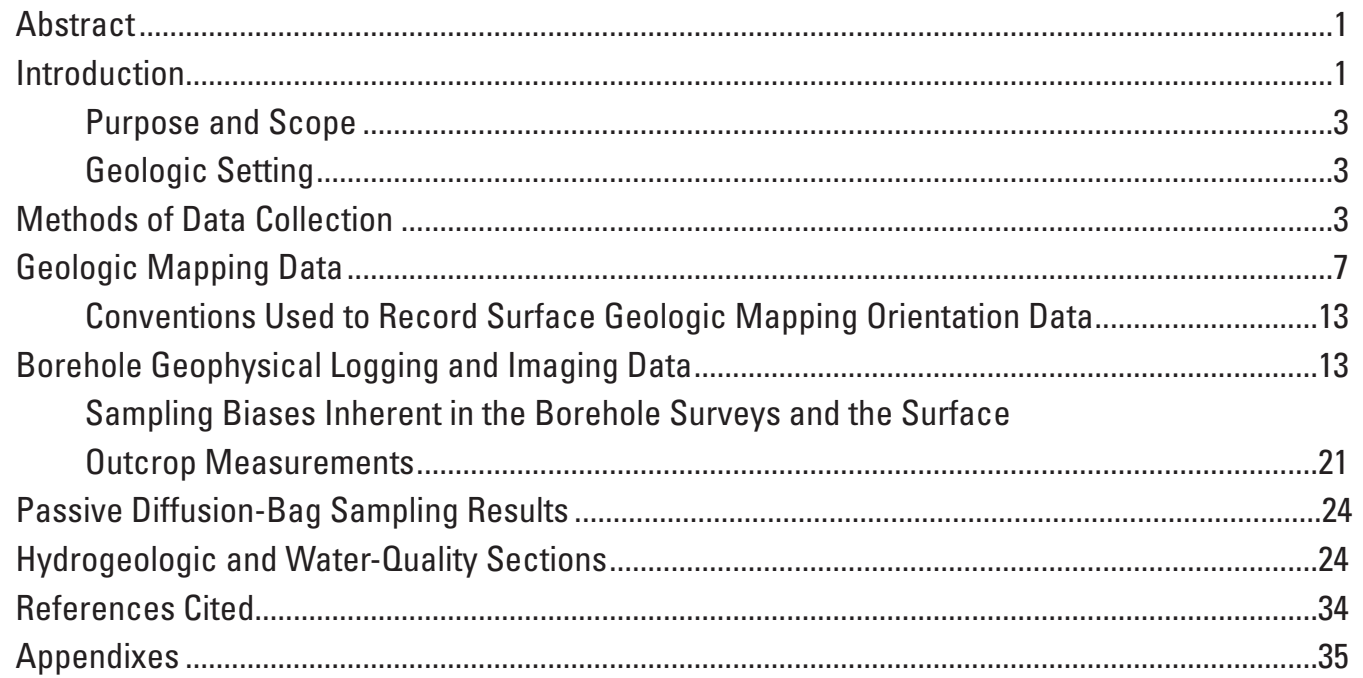

\section{Figures}

1. Map showing location of Person County within regional geologic terranes in the North Carolina Piedmont physiographic province and the GMH Electronics Superfund Site within Person County and associated local geologic units......................2

2. Map showing topography near the GMH Electronics Superfund site, wells logged as part of this study, and lines of cross section shown in figures $25-30 \ldots \ldots \ldots \ldots . . .6$

3. Photograph showing a typical granite boulder field near the GMH Electronics

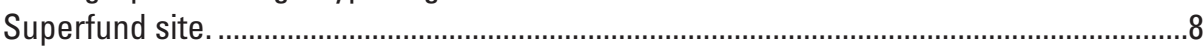

4. Map showing locations of geologic mapping stations and strike orientations of bedding, foliation, and joints measured in outcrops.

5. Rose diagrams showing strike azimuth orientations of foliation measurements; and joint measurements recorded in surface outcrops. Length of petal corresponds to number of measurements.

6. Photograph of a typical granite outcrop showing both steeply dipping and lower-angle joint sets. Booklet is shown for scale.

7. Bar graphs showing the distribution of joint strike azimuth orientations per 20 degree dip-angle categories: low dip-angle joints; medium dip-angle joints; and steeply dipping joints.

8. Optical televiewer images showing typical granite texture in well PS-103, foliation in well PS-106, a mafic lens in well PS-105, and enclaves near low angle and vertical fractures in well PS-100.

9. Optical televiewer images of wells PS-100, PS-099, and PS-106 showing typical open fractures in the subsurface granite near the GMH Electronics Superfund site...

10. Optical televiewer image of secondary weathered and sealed fractures in well PS-105, and typical iron staining along fractures in well PS-103.

11. Rose diagram showing all structures measured in the 15 wells logged near the GMH Electronics Superfund site. 
12. Rose diagram showing strike orientation of subsurface foliation measurements

from the 15 wells logged near the GMH Electronics Superfund site

13. Graphs showing altitude, depth, and inclination angle of primary fractures logged from 15 wells near the GMH Electronics Superfund Site.

14. Rose diagram showing dominant orientations of open fractures measured in the 15 open borehole wells from optical and acoustic televiewer images.

15. Rose diagram map showing the distribution of subsurface structures measured in 15 open borehole wells from optical and acoustic televiewer images.

16. Borehole geophysical logs from well PS-093 showing fracture zones and upward vertical flow at depth.

17. Borehole geophysical logs from well PS-098 showing fracture zones and downward vertical flow at depth.

18. Southwest-to-northeast three-dimensional diagram showing subsurface structures in selected wells

19. Southwest-to-northeast three-dimensional diagram showing subsurface structures in selected wells

20. North-to-south three-dimensional diagram showing subsurface structures in selected wells.

21. North-to-south three-dimensional diagram showing subsurface structures in selected wells.

22. Map showing distribution of 1,1-dichloroethylene concentrations detected in passive diffusion bag samples collected in wells near the GMH Electronic Superfund Site during September 12 through October 3-4, 2011

23. Map showing distribution of 1,1,1 trichloroethane concentrations detected in passive diffusion bag samples collected in wells near the GMH Electronic Superfund Site during September 12 through October 3-4, 2011.

24. Map showing distribution of benzene concentrations detected in passive diffusion bag samples collected in wells near the GMH Electronic Superfund Site during September 12 through October 3-4, 2011.

25. Schematic cross section $A-A$ ' showing depths to and orientations of subsurface borehole fractures and generalized orientation of surface geologic structural features.

26. Schematic cross section $B-B$ ' showing depths to and orientations of subsurface borehole fractures and generalized orientation of surface geologic structural features.

27. Schematic cross section $A-A$ ' showing depths to and orientations of borehole fractures and detected 1,1-dichloroethylene and 1,1,1 trichloroethane concentrations from the passive diffusion bag sampling during October 2011.

28. Schematic cross section $B-B^{\prime}$ showing depths to and orientations of borehole ractures and detected 1,1-dichloroethylene and 1,1,1 trichloroethane concentrations from the passive diffusion bag samping during October 2011

29. Schematic cross section $A-A$ ' showing depths to and orientations of borehole fractures and detected benzene concentrations from the passive diffusion bag sampling during October 2011.

30. Schematic cross section $B-B^{\prime}$ showing depths to and orientations of borehole fractures and detected benzene concentrations from the passive diffusion bag samping during October 2011. 


\section{Tables}

1. Characteristics of the 15 wells logged near of the GMH Electronics

Superfund site

.4

2. Fracture zones monitored using passive diffusion bags from

September 12 through October 3-4, 2011, near the GMH Electronics

Superfund site.

3. FLASH program modeling results for heat-pulse flowmeter logs

collected from the 15 wells near the GMH Electronics

Superfund site

\section{Appendixes 1-8}

The appendix files are available at $h t t p: / / p u b s . u s g s . g o v / d s / 762 /$ in the formats listed below

1. Borehole geophysical logging field notes PDF

2. Heat-pulse flowmeter tool rinse volatile organic compound sample results......MS Excel

3. Geologic structural measurements recorded near the GMH Electronics Superfund site MS Excel

4. Borehole geophysical logs showing depth of fracture zones, borehole flow, and percent contribution of fractures to flow in the well ......................................... PDF

5. Borehole geophysical image logs showing orientations of subsurface structural features. PDF

6. Rose diagrams showing dominant orientations of borehole structural features PDF

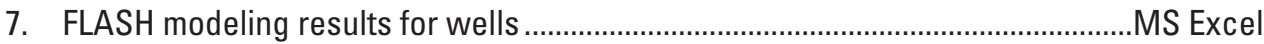

8. Analytical results of the passive diffusion bag sampling October 2011 ...............MS Excel

\section{Conversion Factors}

\begin{tabular}{lcl}
\multicolumn{1}{l}{ Inch/Pound to SI } & \multicolumn{1}{c}{ To obtain } \\
\hline \multicolumn{1}{c}{ Multiply } & By & \multicolumn{1}{c}{ centimeter $(\mathrm{cm})$} \\
inch (in.) & 2.54 & millimeter (mm) \\
inch (in) & 25.4 & meter $(\mathrm{m})$ \\
foot (ft) & 0.3048 & kilometer $(\mathrm{km})$ \\
mile (mi) & 1.609 & meter squared per day $\left(\mathrm{m}^{2} / \mathrm{d}\right)$ \\
$\mathrm{ft}^{2} / \mathrm{d}($ foot squared per day) & 0.09290 & liter per second $(\mathrm{L} / \mathrm{s})$ \\
$\mathrm{gal} /$ min (gallon per minute) & 0.06309 &
\end{tabular}




\author{
Abbrevations \\ ATV acoustic televiewer \\ DCA 1,1-dichloroethane \\ DCE 1,1-dichloroethylene \\ EPA U.S. Environmental Protection Agency \\ IAG interagency grant \\ $\mathrm{Ma}$ mega-annum (million years ago) \\ NCGS North Carolina Geological Survey \\ NPL National Priorities List \\ OTV optical televiewer \\ PDB passive diffusion bag \\ TCA 1,1,1 trichloroethane \\ USGS U.S. Geological Survey
}




\title{
Geophysical Logging and Geologic Mapping Data in the Vicinity of the GMH Electronics Superfund Site near Roxboro, North Carolina
}

\author{
By Melinda J. Chapman, ${ }^{1}$ Timothy W. Clark, ${ }^{2}$ and John H. Williams ${ }^{1}$
}

\section{Abstract}

Geologic mapping, the collection of borehole geophysical logs and images, and passive diffusion bag sampling were conducted by the U.S. Geological Survey North Carolina Water Science Center in the vicinity of the GMH Electronics Superfund site near Roxboro, North Carolina, during March through October 2011. The study purpose was to assist the U.S. Environmental Protection Agency in the development of a conceptual groundwater model for the assessment of current contaminant distribution and future migration of contaminants. Data compilation efforts included geologic mapping of more than 250 features, including rock type and secondary joints, delineation of more than 1,300 subsurface features (primarily fracture orientations) in 15 open borehole wells, and the collection of passive diffusion-bag samples from 42 fracture zones at various depths in the 15 wells.

\section{Introduction}

The GMH Electronics National Priorities List (NPL) Superfund site is located at the intersection of Halifax and Virgilina Roads, approximately 1 mile (mi) northeast of Roxboro, in Person County, North Carolina (fig. 1). Regionally, the study area is located in the eastern part of the Piedmont physiographic province in North Carolina, within an area of metamorphosed intrusive rocks in the Carolina Slate Belt (fig. 1; North Carolina Geological Survey, 1985). The area was later described as the Greensboro Intrusive Suite within the Virgilina Sequence of the Carolina terrane from the map by Hibbard and others (2006) in North Carolina.

${ }^{1}$ U.S. Geological Survey.

${ }^{2}$ Private contractor.
The aquifer in the study area is complex, as elsewhere in the Piedmont physiographic province, consisting of a three-part system of shallow, weathered regolith, intermediate transition zone, and deeper fractured bedrock; the complexity is a result of multiple periods of structural deformation, metamorphism, and igneous intrusion. The weathered regolith component may include soil, saprolite, debris flow material, colluvium, and alluvium. The transition zone consists of includes partially weathered rock that is highly fractured (Chapman and others, 2005). Most of the groundwater-supply wells in the study area are completed in the bedrock part of the aquifer, where water moves through secondary fractures and other complex discontinuities, such as differential weathering along lithologic contacts. The shallow regolith is the primary storage reservoir and is the source of recharge to the deeper bedrock fractures (Heath, 1980, 1983, 1984, 1994). The bedrock has little primary porosity except where secondary openings are present in the form of fractures and other discontinuities. These secondary openings are the primary source of permeability in the bedrock. Thus, the mapping of fractures and other geologic features is critical to the understanding of groundwater transport to wells and the delineation of pathways of contaminant transport.

In June 2010, the U.S. Geological Survey (USGS) received a request from the Environmental Protection Agency (EPA) Region 4 Superfund Section to assist in the development of a conceptual groundwater model in the area of the GMH Electronics Facility NPL Superfund site near Roxboro, North Carolina (formerly the Halifax Road DCE site) through an Interagency Agreement (IAG). The USGS effort included (1) the application of established and state-of-the-science borehole geophysical tools and methods used to delineate and characterize fracture zones in the regolith-fractured bedrock aquifer and (2) assistance toward the development of a conceptual model of flow in the bedrock part of the groundwater system that can be used to evaluate contaminant concentrations and future migration. The USGS effort was done in cooperation with the EPA Region 4 Superfund Section. 


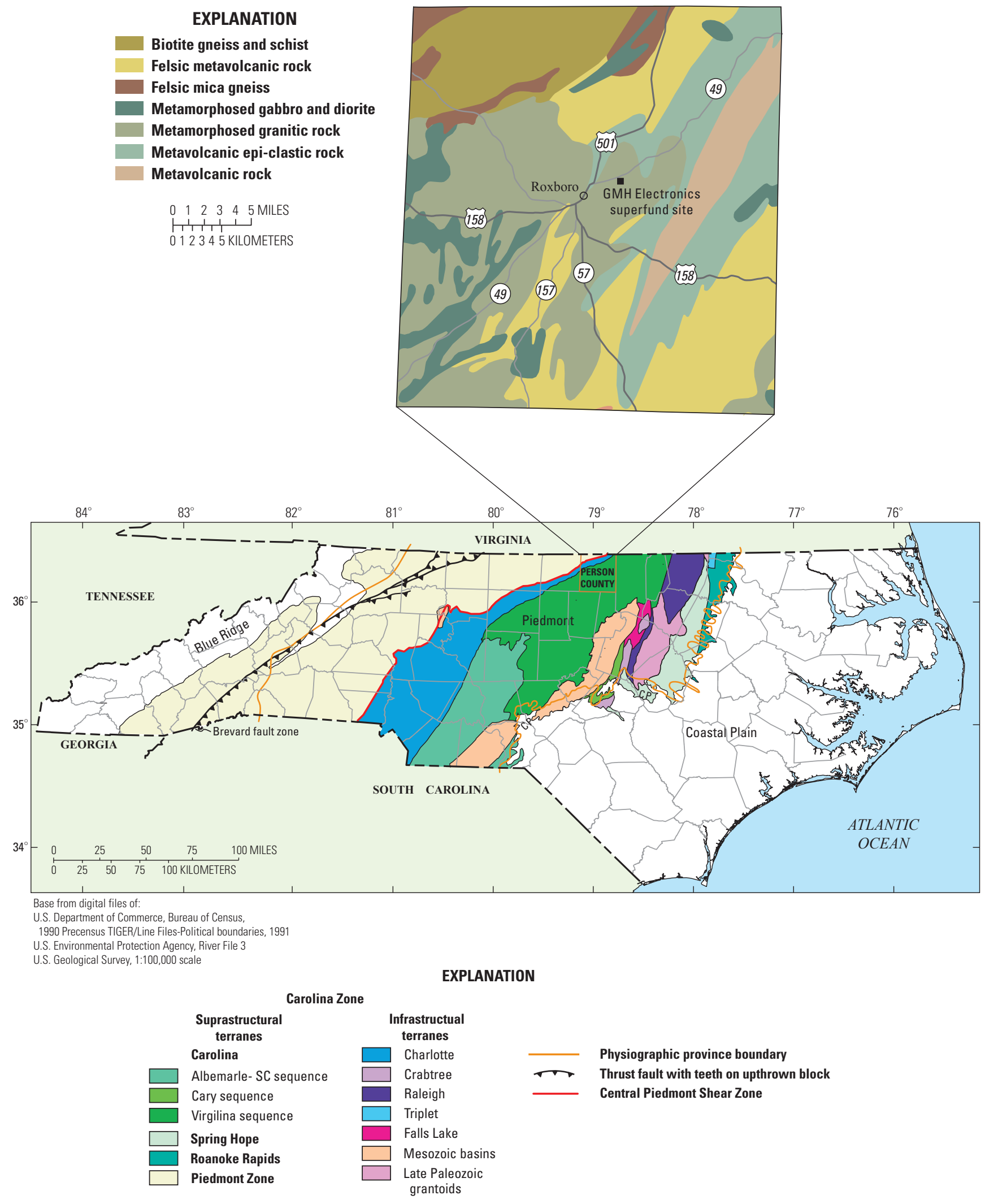

Figure 1. Location of Person County within regional geologic terranes in the North Carolina Piedmont physiographic province and the GMH Electronics Superfund site within Person County and associated local geologic units (modified from North Carolina Geological Survey, 1985 and Hibbard and others, 2002). 


\section{Purpose and Scope}

The purpose of this report is to present geophysical logging, geologic mapping, and groundwater-quality data collected in the vicinity of the GMH Electronics Superfund site near Roxboro, North Carolina. Borehole geophysical logs were used to delineate and characterize fractures zones in 15 open-borehole wells completed within the bedrock part of the aquifer. Geologic mapping was conducted within a 1-mile radius of the former GMH Electronics site and included the collection of data at 136 stations. Groundwater-quality samples were collected using passive diffusion-bag samplers at two to three fractures zones in each of the 15 wells that were geophysically logged. A total of 46 samples were analyzed for volatile organic compounds, including 4 quality assurance samples.

\section{Geologic Setting}

Field geologic-mapping observations indicate the GMH Electronics NPL site is located within the Roxboro metagranite (Briggs and others, 1978) outcrop area. The Roxboro metagranite is a complex igneous body that intruded older volcanic and volcanoclastic rocks about 575 million years ago (Ma) during the Ediacaran Period (Neoproterozoic Era). The older volcanic and volcaniclastic rocks of the Carolina Terrane (Hibbard and others, 2002) were deposited at least 25 million years earlier, because they were metamorphosed, faulted, and folded by the 600 Ma Virgilina deformation event. Virgilina sequence rocks are located a few miles from the site to the north, east, and west of the GMH site. The Roxboro metagranite and the surrounding metavolcanic rocks underwent a long period of erosion until they were subjected to a second and much later deformation event during the middle Paleozoic ( $450 \mathrm{Ma}$ ) (Hibbard and others, 2002). Since that time, the region has continued to experience erosion and unroofing, resulting the present exposure of metagranite and metavolcanic rocks at land surface.

The Roxboro metagranite is predominately granitic in composition, although locally contains phases that are more representative of a granodiorite (Briggs and others, 1978). In addition, the pluton contains numerous enclaves and (or) xenoliths of gabbro and metavolcanic rock of the Carolina Terrane. Recent mapping of the North Carolina Geological Survey (NCGS) in the Caldwell and Cedar Grove topographic quadrangles within the southern portions of the Roxboro pluton indicate that the pluton is intruded by many diorite to gabbro dikes that trend northeast-southwest (Phil Bradley, North Carolina Geological Survey, written commun., 2010).

In the area of study around the GMH site, several of these dikes intrude the Roxboro metagranite. Field observations made as part of the current study indicate that these dikes appear to have experienced the same metamorphism as the granite and are interpreted to have intruded the granite shortly after its formation in the Neoproterozoic Era. These dikes form discontinuities in the granite that may serve as permeable pathways in the subsurface.

Outcrops of the Roxboro metagranite are abundant in the area of the GMH site; unlike other areas of the North Carolina Piedmont, however, the majority of outcrops are away from streams and creeks. Most exposures occur as rounded boulder outcrops or pavements along topographic highs or as large boulder fields along the slope breaks of hillsides. Locally, boulders are so numerous that it is difficult to distinguish outcrops from float. Some rounded boulder outcrops exceed 4 meters (about 13 feet) in diameter. Many outcrops exhibit large planar joints or joint sets. Moderately to steeply dipping joints were the most common encountered and typically were quite planar and smooth. Sub-horizontal to low-angle joints, conversely, were more random in orientation, appeared rounded to curvi-planar in some locations, and were highly weathered at the surface.

\section{Methods of Data Collection}

Borehole geophysical logs and surface geologic mapping methods were used to characterize both subsurface and surface features in the fractured bedrock and overlying regolith near the GMH Electronics Superfund site (fig. 1). Borehole geophysical logs were collected in 15 wells in the GMH Electronics site area from March through August 2011 (table 1; fig. 2). These subsurface data were compared to local surface geologic mapping data collected by an independent contractor during June 2011. Passive diffusion bags were used to collect samples from the fifteen wells at two to three fracture zones per well for volatile organic compound analyses during September through October 2011.

Surface geologic mapping consisted of noting the location of the outcrop, rock types (lithology and textural characteristics), and measuring orientations of structural features including joints and foliation (where present). Not all joints were measured because they were too numerous to conduct cost-effective mapping; therefore, only joints that appeared to represent the predominant joint-set orientation were measured.

Logs collected from each of the 15 wells included caliper, electrical resistivity, natural gamma, fluid temperature and resistivity, heat-pulse flowmeter (both ambient and stressed), and optical televiewer (OTV). Additionally, acoustic televiewer (ATV) logs were run in seven wells where the water was murky (poor visibility from OTV image). Field notes from geophysical logging activities are included in appendix 1 . Rinse samples from borehole logging tools were collected prior to geophysical logging, between the logging of selected wells, and subsequent to the completion of logging. These rinse samples were analyzed for volatile organic compounds to ensure that no contaminants were transferred from well to well as part of the geophysical logging process. Analytical data from the boreholelogging-tool rinse samples are included as appendix 2 .

Geophysical logging was used to characterize subsurface bedrock structures by primary lithology, fracture characteristics, foliation (if present), secondary lithologies, and lithologic contacts. Fracture zone characteristics delineated in the 15 wells logged as part of this study include depth, strike orientation, dip angle, measured flow, and modeled hydraulic characteristics. Fracture zones were delineated for each well using all of the available borehole logs, including visual delineation from OTV images, increases in caliper-log diameter, resistivity decreases (below the water level), and inflections or slope changes in the fluid temperature or fluid resistivity logs.

Continuous, oriented digital color images of the granite bedrock in the subsurface were recorded from OTV image logs. These logs 


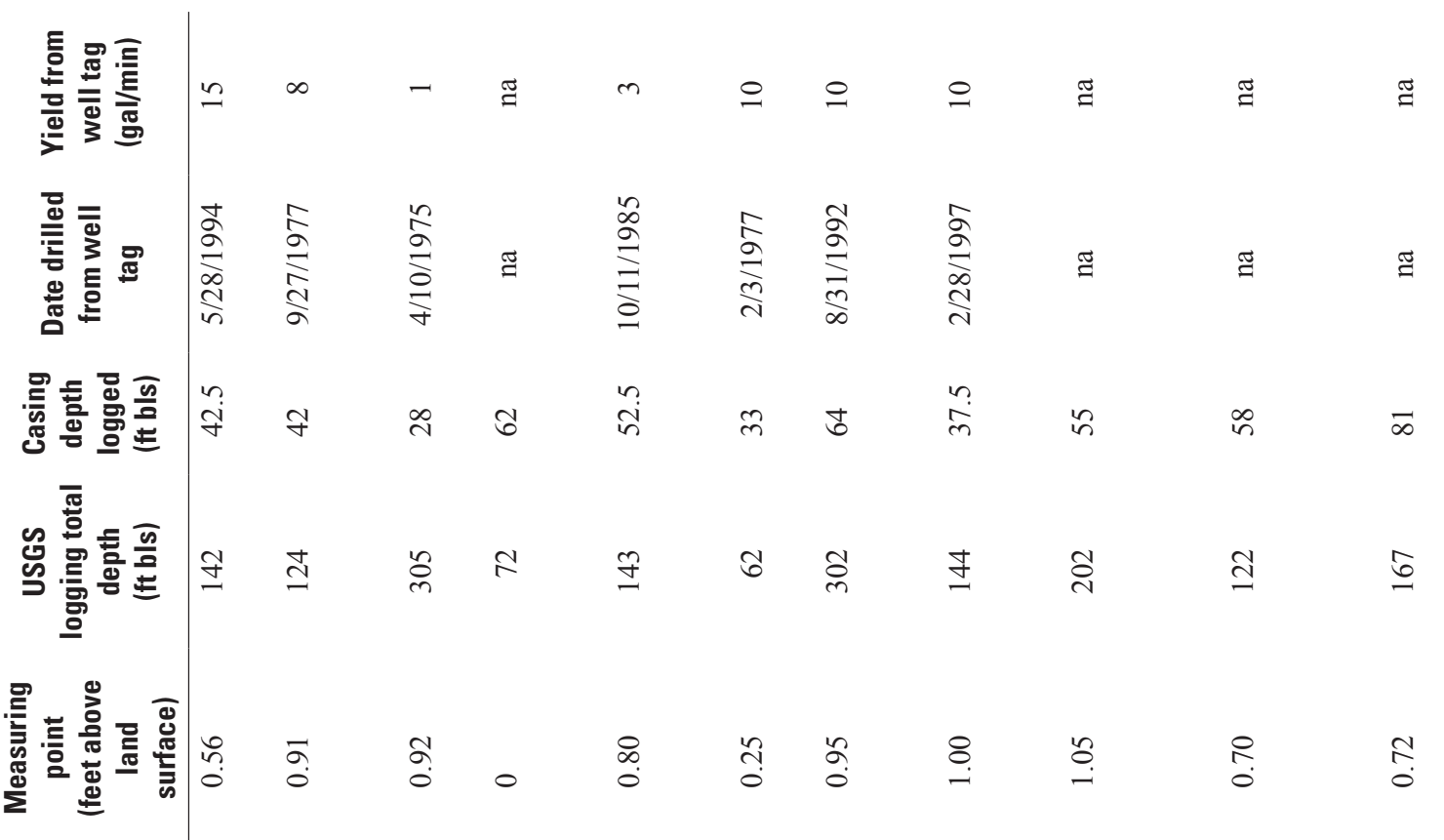

\begin{tabular}{|c|c|c|c|c|c|c|c|c|c|c|}
\hline 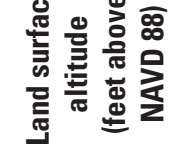 & $\stackrel{8}{n}$ & $\stackrel{\infty}{n}$ & $\stackrel{\overbrace{}}{\curvearrowright}$ & $\stackrel{\infty}{\mathbb{N}}$ & $\stackrel{g}{I}$ & $\stackrel{P}{i}$ & $\sqrt{2}$ & $\stackrel{⿱}{2}$ & & $\stackrel{\infty}{\stackrel{\infty}{r}}$ \\
\hline
\end{tabular}

\begin{tabular}{|c|c|c|c|c|c|c|c|c|c|c|}
\hline 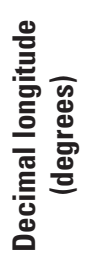 & $\begin{array}{l}1 \\
0 \\
0 \\
0 \\
0 \\
o \\
0 \\
0 \\
0 \\
\vdots \\
0 \\
0 \\
0 \\
1\end{array}$ & 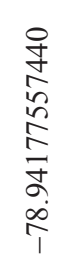 & 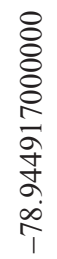 & 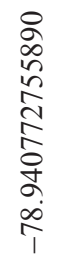 & 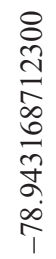 & 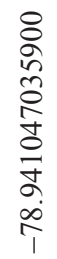 & 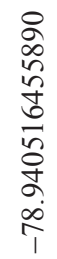 & 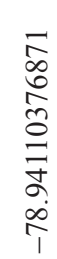 & 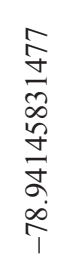 & 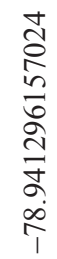 \\
\hline
\end{tabular}

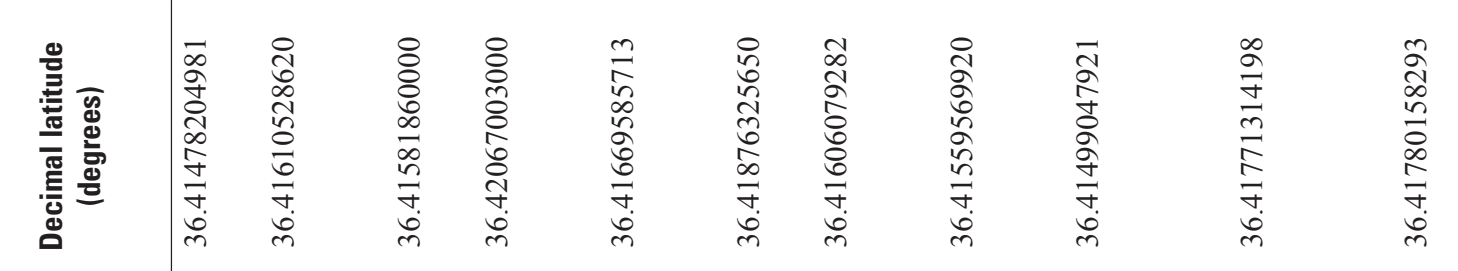

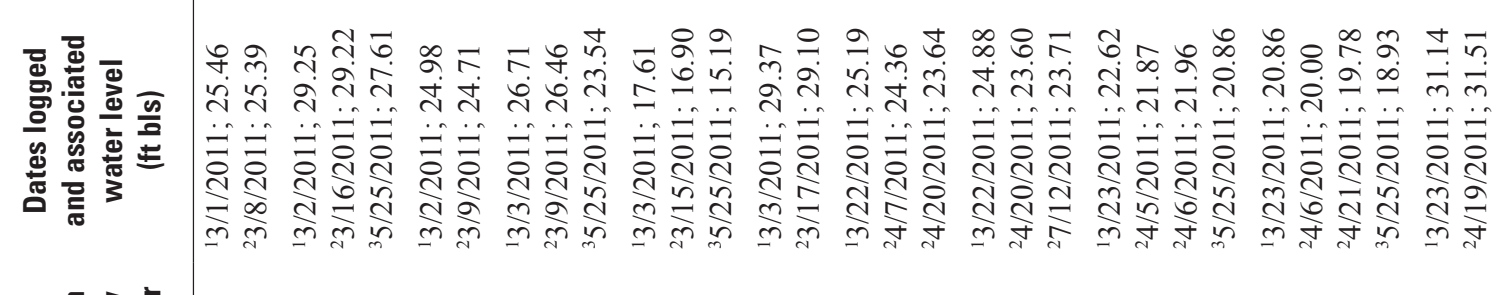

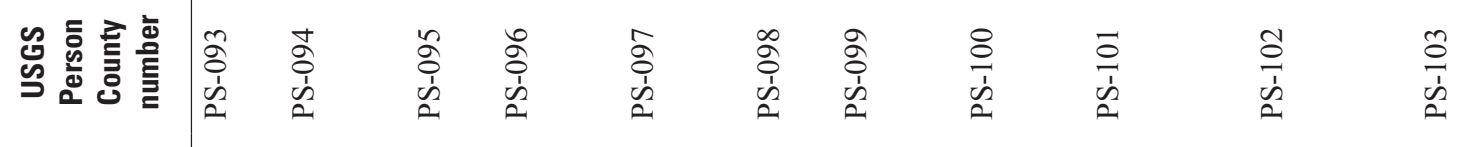

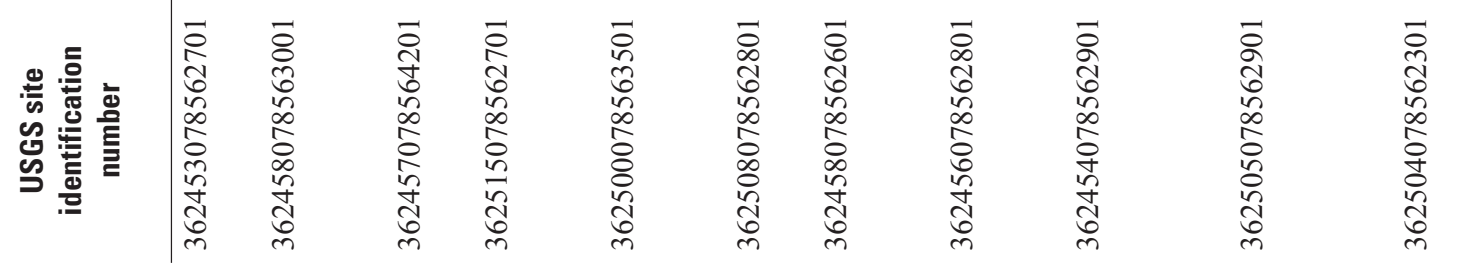




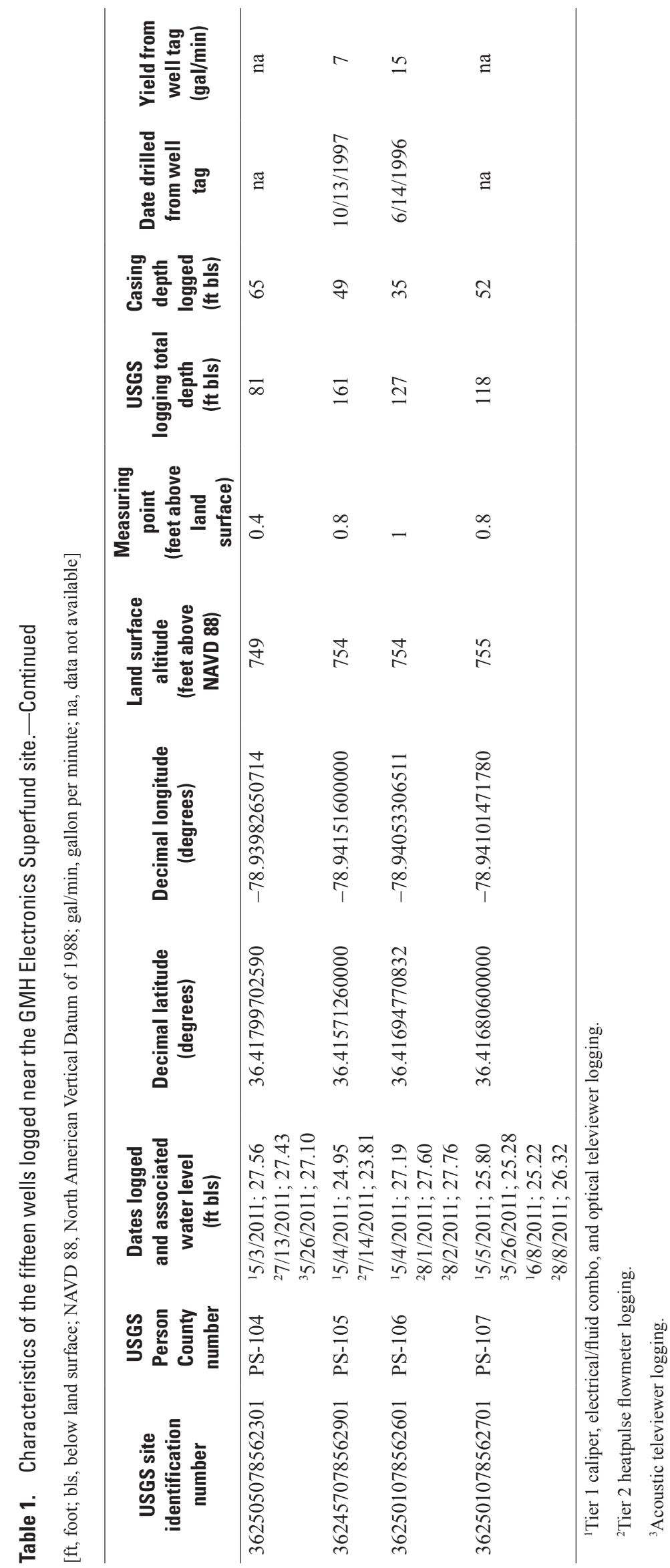




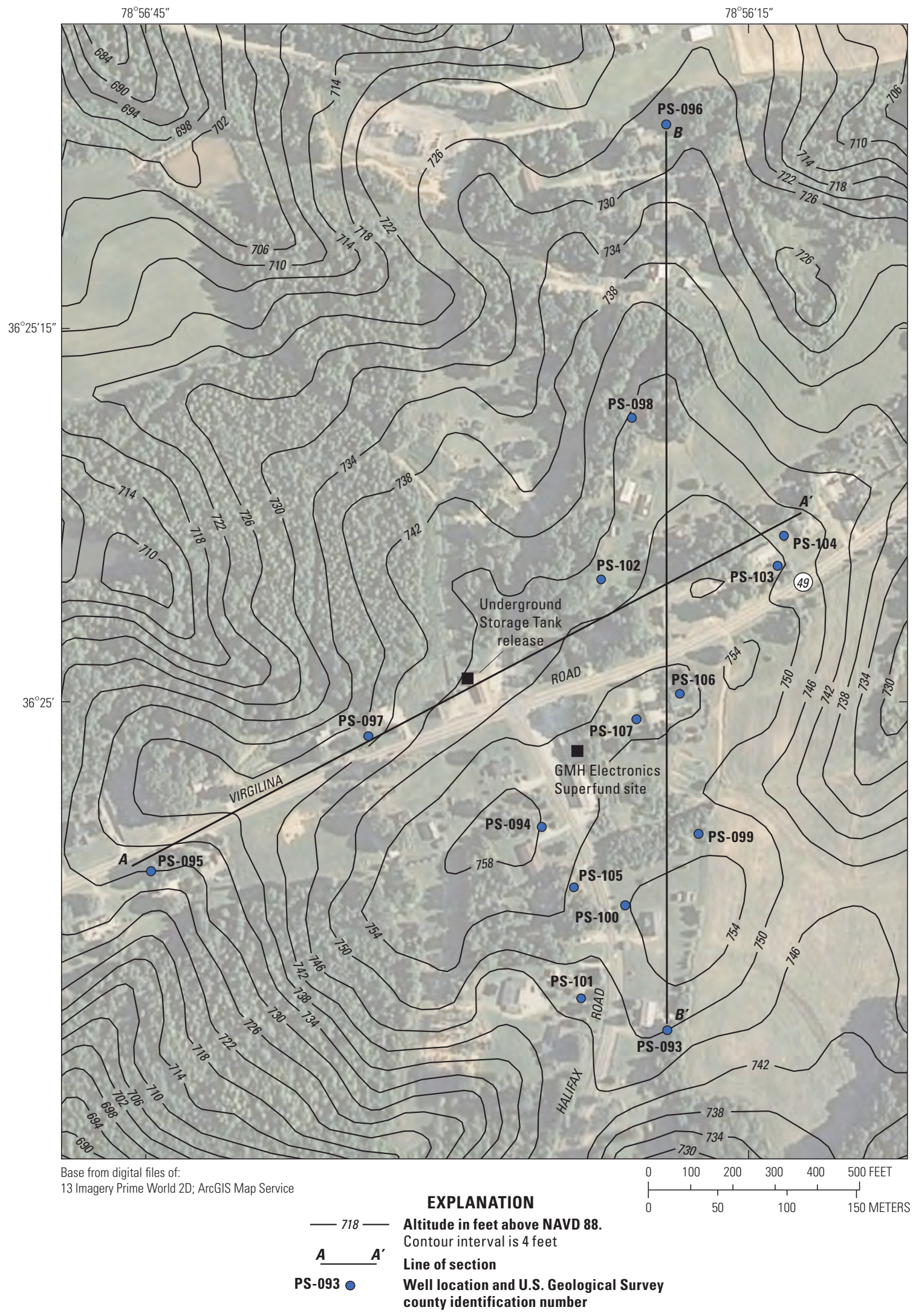

Figure 2. Topography near the GMH Electronics Superfund site, wells logged as part of this study, and lines of cross section shown in figures $25-30$. 
are oriented using a magnetometer built into the borehole tool, and thus, the orientations of features such as fractures can be determined by using adjustments for local magnetic declination. Images of the granite were used to interpret texture, identify igneous enclaves, and delineate secondary compositional changes, such as the presence mafic lenses. Where the water in the well was too cloudy, an acoustic televiewer tool was used to image the fractures and determine orientations.

Orientations of subsurface fractures (both open and sealed), foliation, and lithologic contacts were determined from the OTV and ATV image logs using WellCad software ( aLt, 2010). Fracture orientations were determined from OTV and ATV images, which were corrected for magnetic declination (http://www.ngdc.noaa.gov/ geomagmodels/Declination.jsp; accessed April 2012) and borehole deviation. Orientations interpreted from the OTV image logs were adjusted for a local magnetic declination of $9^{\circ}$ west and for measured borehole deviation. Subsurface geologic features were imported into Rockworks software (Rockware, Inc., 2010) for statistical analyses using rose diagrams and three-dimensional display of fracture planes at depth. The fracture orientation data were compared and used along with surface geologic mapping data to build a conceptual model of flow in the bedrock part of the aquifer in the study area.

Fracture zones were selected for heat-pulse flowmeter logging (that is, stationary measurements of vertical borehole flow above and below the fracture zone) based on interpretations from caliper, electrical resistivity, and fluid (temperature and specific conductance) logs, and OTV/ATV image logs and interpretations. Results from both ambient (natural flow) and stressed (pumped flow) measurements from heat-pulse flowmeter logs were modeled for aquifer properties (hydraulic head differences, transmissivity, and radius of influence) using the recently published USGS FLASH program (Day-Lewis and others, 2011; http://waterusgs.gov/ogw/flash/). Positive heat-pulse flow measurements indicated upflow, whereas negative heat-pulse flow measurements indicated downflow.

To evaluate the distribution of volatile organic contaminants within the vertical boreholes in the wells, two to three fracture zones were selected for passive diffusion bag (PDB) monitoring (Vroblesky, 2001a, b) in each of the 15 wells, based on interpretations of flow measured near delineated and modeled contribution of the fracture zones. Since the mid-1990s, PDBs have been used in numerous studies as a means of screening open boreholes or multiple-screened wells for vertical contaminant distribution prior to the use of more expensive monitoring methods such as straddle packers.

A total of 42 fracture zones selected from borehole geophysical logs and images and heat-pulse flowmeter data modeling were monitored using the PDBs from September 12 through October 3-4, 2011 (table 2). PDBs were lowered to the average depth of the selected fractures and remained in the well for the entire monitoring period (2-3 weeks). The PDBs were then retrieved uphole, and water from the bag was emptied into 40-milliliter $(\mathrm{mL})$ glass vials for analysis of volatile organic compounds. The samples were analyzed by the EPA National Exposure Research Laboratory in Athens, Georgia (http://www.epa.gov/greeningepa/facilities/athens-ord.htm; accessed April 2012). Trip-blank and replicate-sample analyses were also conducted for quality assurance and quality control.
Table 2. Fracture zones monitored using passive diffusion bags from September 12 through October 3-4, 2011.

[All depths are in feet below land surface; na, not applicable]

\begin{tabular}{cccccc}
\hline $\begin{array}{c}\text { USGS } \\
\text { county } \\
\text { well } \\
\text { number }\end{array}$ & $\begin{array}{c}\text { Bag } \\
\text { depth 1 }\end{array}$ & $\begin{array}{c}\text { Bag } \\
\text { depth 2 }\end{array}$ & $\begin{array}{c}\text { Bag } \\
\text { depth 3 }\end{array}$ & $\begin{array}{c}\text { Casing } \\
\text { depth }\end{array}$ & $\begin{array}{c}\text { Total well } \\
\text { depth }\end{array}$ \\
\hline PS-093 & 70 & 122 & na & 42.5 & 141.5 \\
PS-094 & 49 & 65 & 123 & 42 & 124.4 \\
PS-095 & 39 & 85 & 137 & 28 & 304.5 \\
PS-096 & 64 & 70 & na & 62 & 72.4 \\
PS-097 & 55 & 98 & 139 & 52.5 & 143 \\
PS-098 & 40 & 54 & 60 & 33 & 62.4 \\
PS-099 & 74 & 87 & 276 & 64 & 302 \\
PS-100 & 45 & 113 & 139 & 37.5 & 144 \\
PS-101 & 79 & 149 & 196 & 55 & 202.4 \\
PS-102 & 65 & 83 & 119 & 58 & 122 \\
PS-103 & 110 & 124 & 153 & 81 & 167 \\
PS-104 & 68 & 74 & na & 65 & 80.5 \\
PS-105 & 99 & 105 & 152 & 49 & 161 \\
PS-106 & 41 & 76 & 120 & 35 & 127 \\
PS-107 & 55 & 70 & 103 & 52 & 118 \\
\hline
\end{tabular}

\section{Geologic Mapping Data}

Structural data recorded as part of local geologic mapping within a 1-mi radius of the GMH site as part of this study during June 2011 indicate that most of outcrops near the GMH Electronics site are massive and, hence, referred to as a "granite" (fig. 3 and app. 3). The granite is described as massive, medium-grained intrusive or weakly foliated (fig. 3). The rock type at 91 percent of the 137 mapping stations was described as granite (app. 3); rocks mapped at other stations included weakly layered and banded, semimassive and aphanitic dacites, pegmatite, amygdaloidal metagabbro, and foliated felsic crystal and crystal tuffs. Figure 4 shows the areal distribution of geologic structural data in the study area. Weak foliation was measured, having a dominant strike orientation range of $20^{\circ}-40^{\circ}$ (fig. $5 A$ ) ( 9 of 17 outcrops), dipping to the southeast at angles ranging from $25^{\circ}$ to $86^{\circ}$, averaging $60^{\circ}$ (app. 3).

Numerous joint features were measured (205 of 252 measurements; app. 3), with spacing ranging from less than 1 to greater than 3 meters (about 10 feet). A photograph of a typical outcrop showing joint sets is shown in figure 6 .

The dominant strike orientations for the joint sets measured was $20^{\circ}-30^{\circ}$ (fig. $5 B$ ). For the low dip-angle joint, dipping 30 degrees or less (19 of 205 measurements), the primary strike orientation was $141^{\circ}-160^{\circ}$ (fig. $7 A$ ). The medium dip-angle joint sets, dipping $31^{\circ}-60^{\circ}$ ( 33 of 205 measurements), had variable strike orientations (fig. $7 B$ ). For the steeply dipping joints - dipping $61^{\circ}$ or greater (153 of 205 measurements) - dominant strike orientations were $0^{\circ}-40^{\circ}, 101^{\circ}-140^{\circ}$, and $201^{\circ}-220^{\circ}$ (fig. $7 C$ ). 


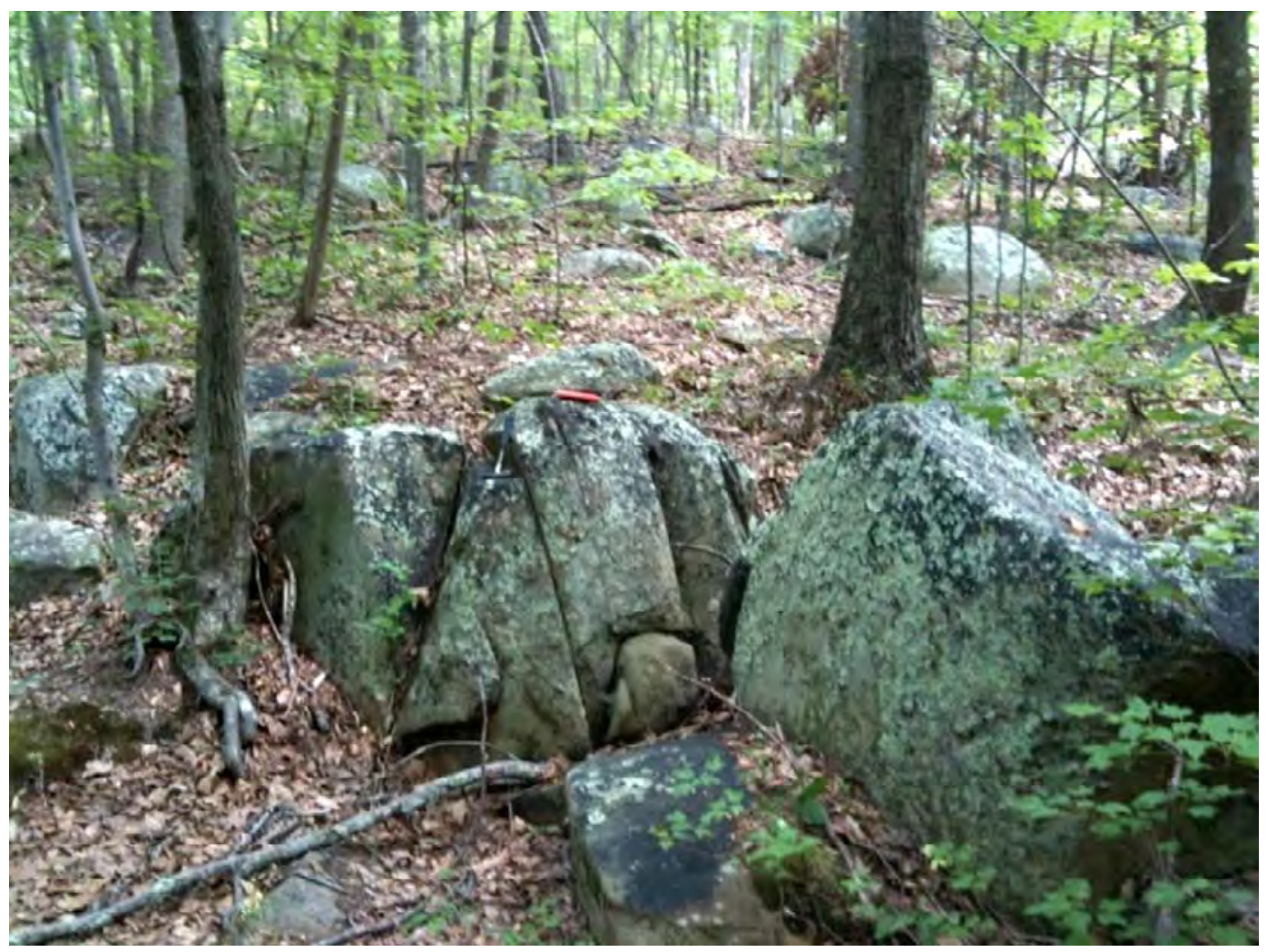

Figure 3. A typical granite boulder field near the GMH Electronics Superfund site. 


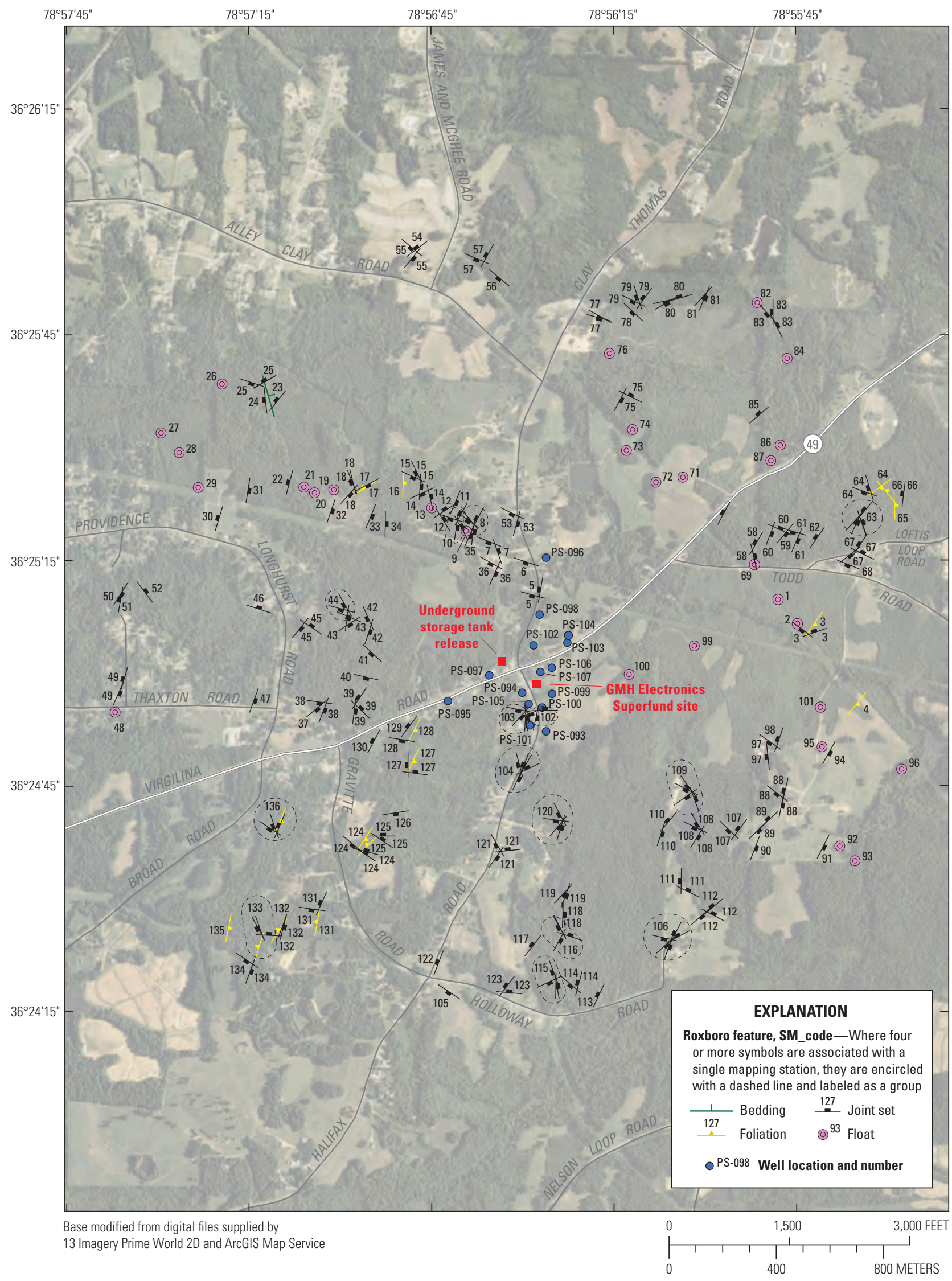

Figure 4. Locations of geologic mapping stations and strike orientations of bedding, foliation, and joints measured in outcrops. 


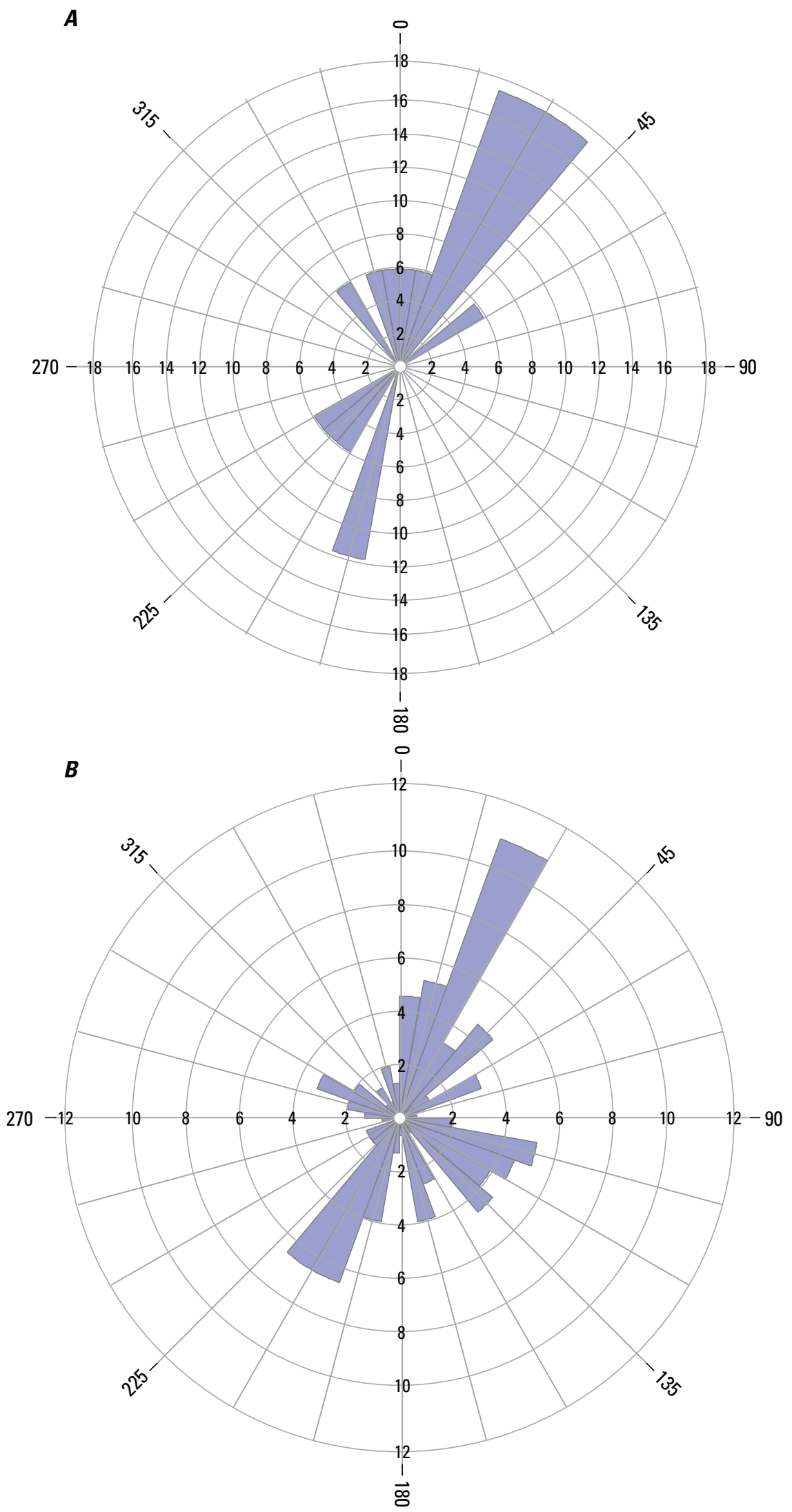

Figure 5. Strike azimuth orientations of $(A)$, foliation measurements; and $(B)$, joint measurements recorded in surface outcrops. Length of petal corresponds to percent of the total number of measurements. 


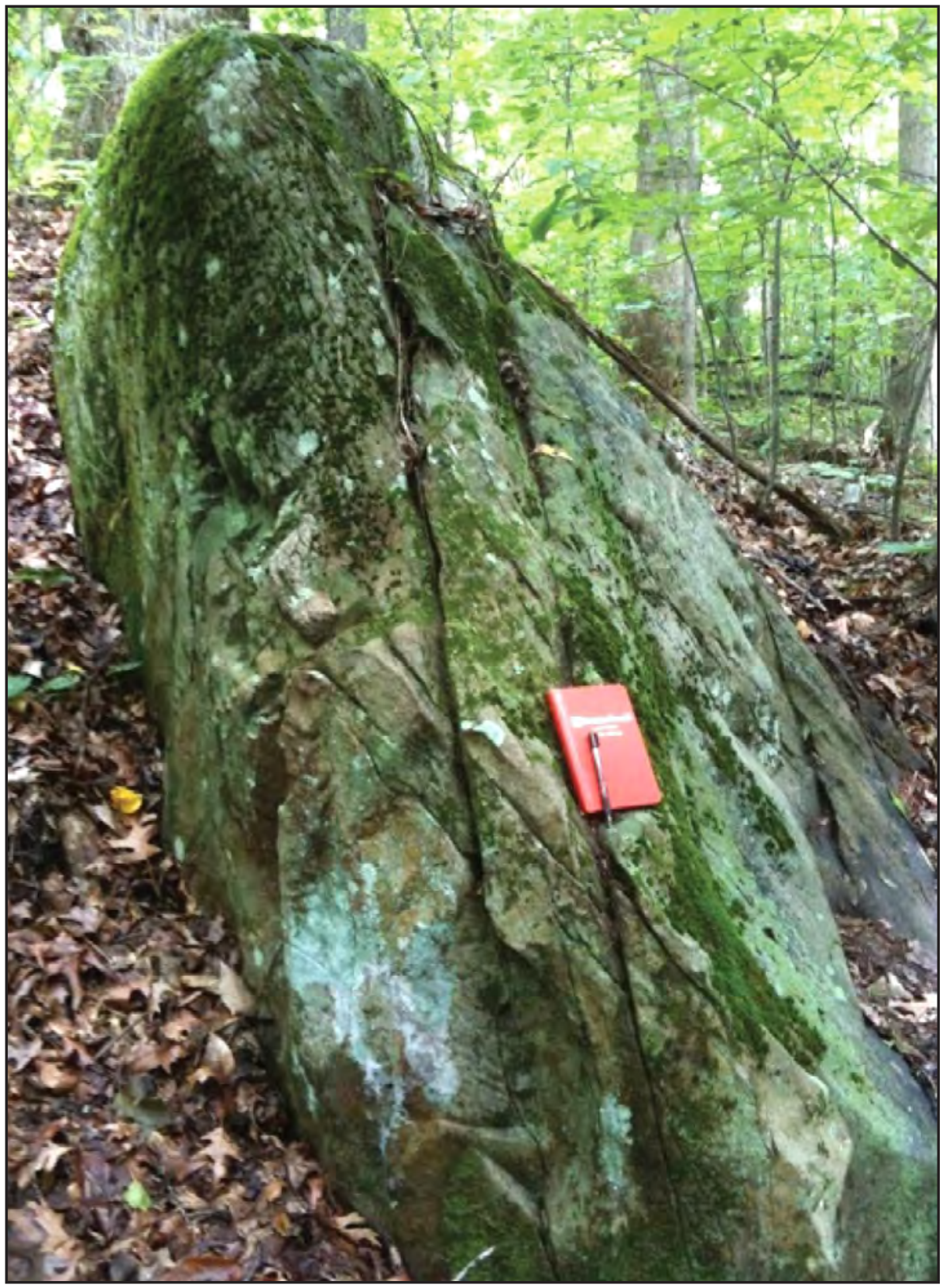

Figure 6. Photograph of a typical granite outcrop showing both steeply dipping and medium-angle joint sets. Booklet is shown for scale. 

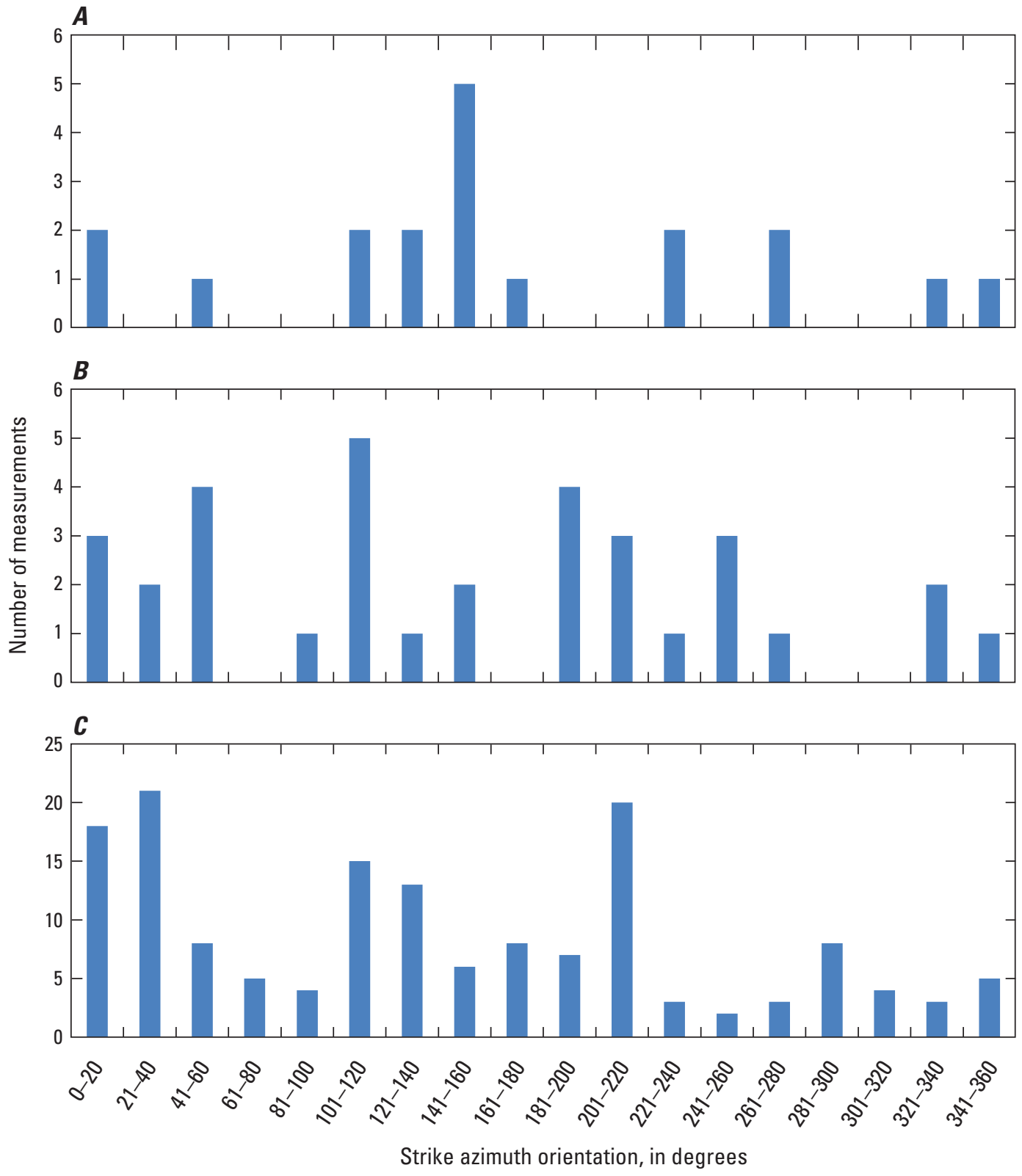

Figure 7. Bar graphs showing the distribution of joint strike azimuth orientations per 20 degree dipangle categories: $(A)$ low dip-angle joints; $(B)$ medium dip-angle joints; and $(C)$ steeply dipping joints. 


\section{Conventions Used to Record Surface Geologic Mapping Orientation Data}

Bedrock discontinuities, such as foliation and joints, measured and recorded for this study are planar features. Dip directions were recorded using the convention that horizontal planes are recorded as having $0^{\circ}$ dips and vertical features as having $90^{\circ}$ dips, with intermediate dip-angles ranging between these two extremes. For planar features, strike is defined as the compass orientation of the horizontal line lying within that plane. Strike azimuths of $0^{\circ}$ to $360^{\circ}$ were recorded using the familiar convention in which $0^{\circ}$ and $360^{\circ}$ correspond to true north, $90^{\circ}$ corresponds to east, $180^{\circ}$ corresponds to south, and $270^{\circ}$ to west. Because all lines extend in two directions, bedrock discontinuities were measured and recorded using the right-hand rule convention (strike azimuth is measured with the dip inclined toward the right). Two planar features assigned strikes that are parallel (for example, $45^{\circ}$ and $225^{\circ}$ ) differ in that one feature dips to the southeast and the other to the northwest, respectively (Chapman and Huffman, 2011).

\section{Borehole Geophysical Logging and Imaging Data}

The 15 wells used for borehole geophysical logging generally were located within a 1/3-mi radius of the GMH site (fig. 2 and table 1; appendixes 4 and 5). Well depths ranged from about 62 to 305 feet (ft) below land surface. The casing depths compiled in table 2 indicate the inferred regolith thickness ranges from about 28 to $81 \mathrm{ft}$. The former private supply wells were drilled from 1975 through 1997 and had reported yields ranging from 1 to 15 gallons per minute ( gal $/ \mathrm{min}$ ) (table 1). Groundwater levels measured in all 15 wells during March through August 2011 ranged from 15.19 to $31.51 \mathrm{ft}$ below land surface.

Figure 8 shows examples of typical (OTV) images of the granite bedrock and secondary textural features. Fractures were characterized as either primary (open), secondary (partially open or weathered), or sealed, as shown in appendix 5. Figure 9 shows typical open subsurface fractures and figure 10 shows typical secondary and sealed subsurface fractures logged in the 15 wells near the GMH Electronics Superfund site.

More than 1,300 subsurface structural measurements (orientations) were interpreted from optical and acoustic televiewer images collected from the 15 wells logged near the GMH Electronics site (fig. 2). Visible foliation was measured, but was very limited in distribution. (fig. $8 B$ ). Fracture characterization included primary (open, fig. 9), secondary (partially open/weathered), and sealed fractures (often filled with secondary minerals) (fig. 10). Figure 11 presents strike orientations for all structures measured in the 15 wells logged as part of this study. The subsurface structure dataset indicates that the most common strike orientations are $20^{\circ}-30^{\circ}$, $10^{\circ}-20^{\circ}$, and $120^{\circ}-160^{\circ}$ (fig. 11). Subsurface structural orientations for individual wells are shown in appendix 6 . The subsurface foliation measurements (fig. $8 B$ ) were not common, composing approximately 3 percent of the subsurface dataset, but the dominant orientation of $20^{\circ}-30^{\circ}$ (fig. 12) parallels that of the surface foliation data (fig. $5 A$ ).

Typical open or primary subsurface fractures logged in the 15 wells in the study area are similar to those shown in figure 9, having apertures ranging from 1 to 21 inches (in.) and borehole diameters of up to $20 \mathrm{in}$., which is the limit of the caliper logging tool used. The primary open fractures were between about 593 and $716 \mathrm{ft}$ in altitude, 35 to $152 \mathrm{ft}$ below land surface, and variable in inclination angle (fig. 13).

The dominant strike orientations for the open fractures were $150^{\circ}-160^{\circ}, 160^{\circ}-170^{\circ}, 170^{\circ}-180^{\circ}, 20^{\circ}-30^{\circ}$, and $140^{\circ}-150^{\circ}$ (fig. 14 and app. 6); the average dip angle for the open fractures was $41^{\circ}$. The $20^{\circ}-30^{\circ}$ set parallels the dominant joint set strike measured in all surface outcrops (fig. $5 B$ ) and a steeply dipping joint subset (fig. $7 C$ ). The $150^{\circ}-160^{\circ}$ and $140^{\circ}-150^{\circ}$ fracture orientations parallel the low dip-angle joint set measured in outcrops (fig. $7 \mathrm{~A}$ ). Other joint sets measured in outcrops were not observed in the wells, which is probably a result of vertical sampling bias (discussed later). The $160^{\circ}-180^{\circ}$ fracture sets observed in the wells were not predominant in the surface-outcrop measurements, which again, is most likely a result of the sampling bias discussed later.

The areal distribution of structures measured in the 15 wells logged is shown in figure 15 The most common dominant fracture orientation within the well set was $151^{\circ}-160^{\circ}$, which was measured in five wells. Other dominant orientations measured in 4 of the 15 wells were $21^{\circ}-30^{\circ}, 91^{\circ}-100^{\circ}$, $111^{\circ}-120^{\circ}, 131^{\circ}-140^{\circ}$, and $181^{\circ}-190^{\circ}$. The $21^{\circ}-30^{\circ}$ primary subsurface fracture orientation parallels that of surface foliation and joints (fig. 5). The $111^{\circ}-120^{\circ}$ and $131^{\circ}-140^{\circ}$ subsurface fracture sets were measured as secondary surface joint sets (fig. 5B).

Ambient vertical groundwater flow was measured in only 3 of the 15 wells-PS-093, PS-096, and PS-098 (app. 7). Figures 16 and 17 and appendix 7 show typical borehole geophysical logs in which fracture zones were delineated and flow was measured and modeled. For ambient measurements, measured flow often was near zero or "no flow." Values of 0.01 to 0.02 gallons per minute $(\mathrm{gal} / \mathrm{min})$ are near the lower resolution of the measuring tool and, thus, may be considered "noise."

In well PS-093 (fig. 16), inflow is modeled at the 122-ft fracture zone, outflow is modeled near the 70 - $\mathrm{ft}$ fracture zone, and flow is upward between the two zones (see FLASH model results in app. 7A). In well PS-098 (fig. 17), inflow is at the $41-\mathrm{ft}$ fracture zone, outflow is near the 53 - $\mathrm{ft}$ fracture zone, and flow is downward between the two zones. Flow direction 

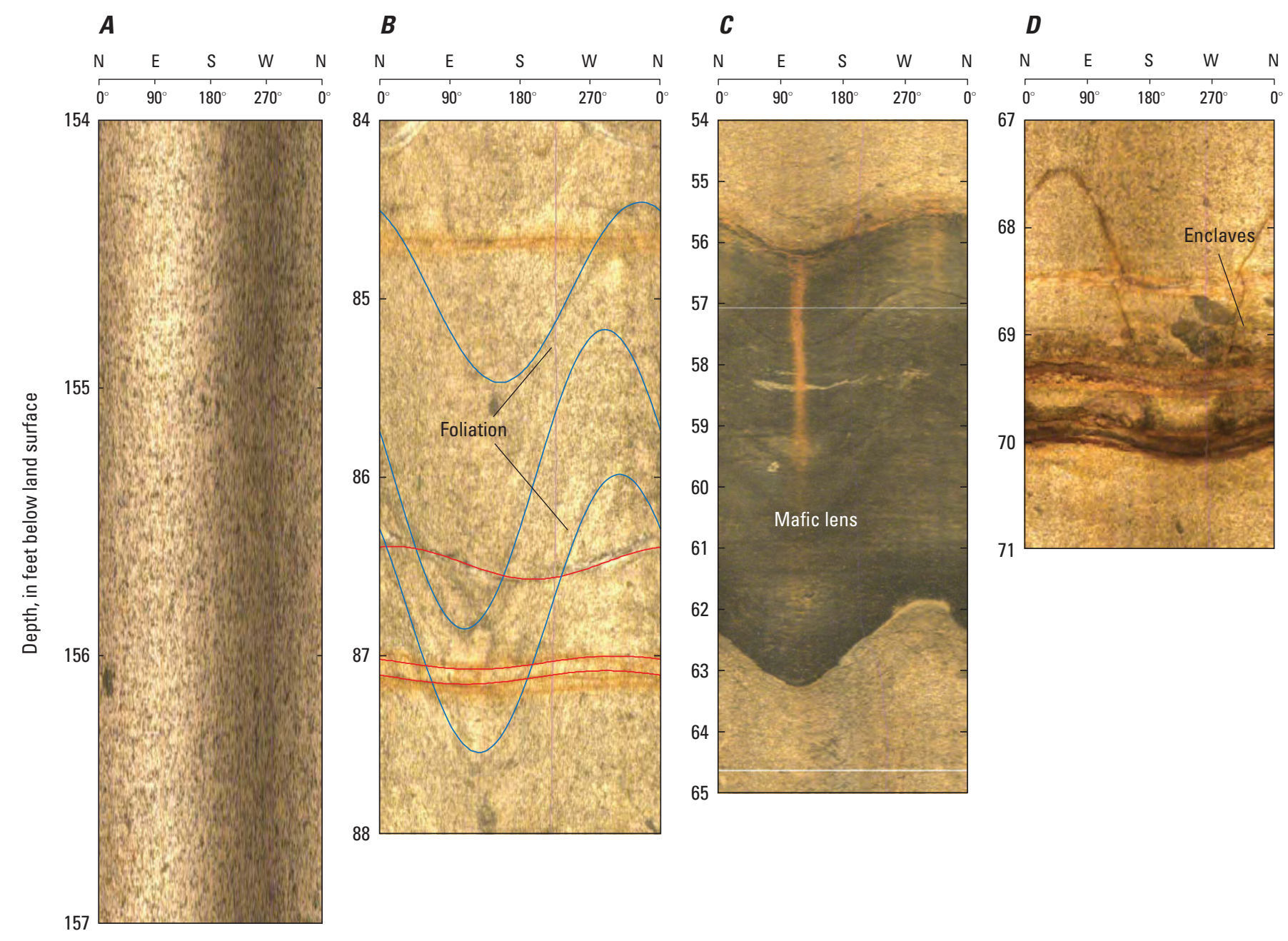

Figure 8. Optical televiewer images showing $(A)$ typical granite texture in well PS-103, $(B)$ foliation in well PS-106, $(C)$ a mafic lens in well PS-105, and (D) enclaves near low angle and vertical fractures in well PS-100. 

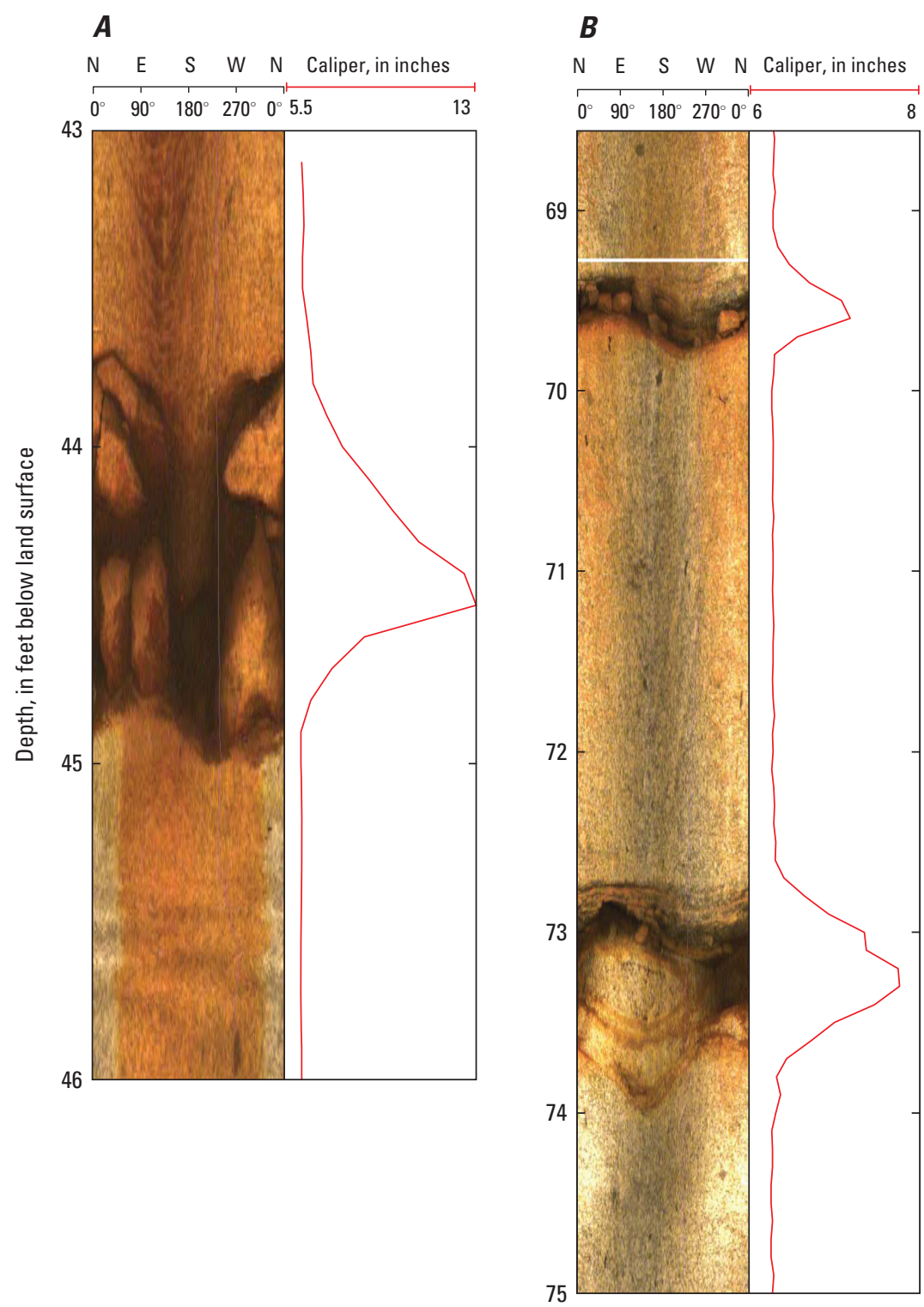

\section{C}

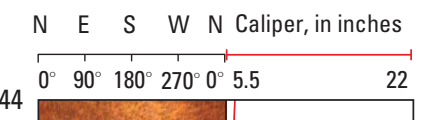

44

45

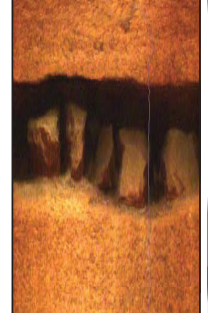

46

47

48

-
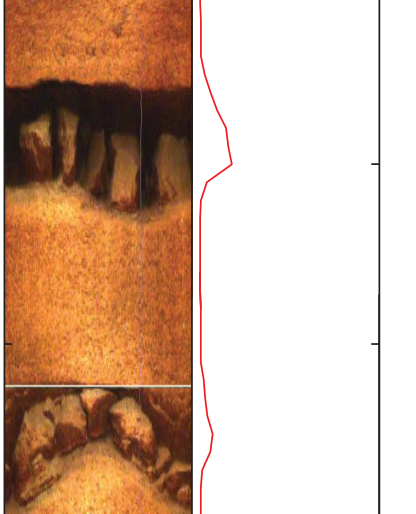

49

50

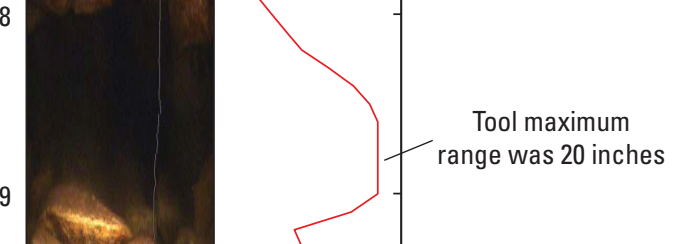

52

51

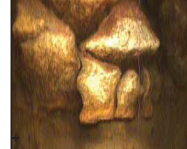

5
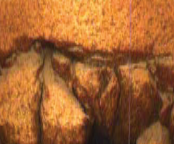

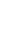

75

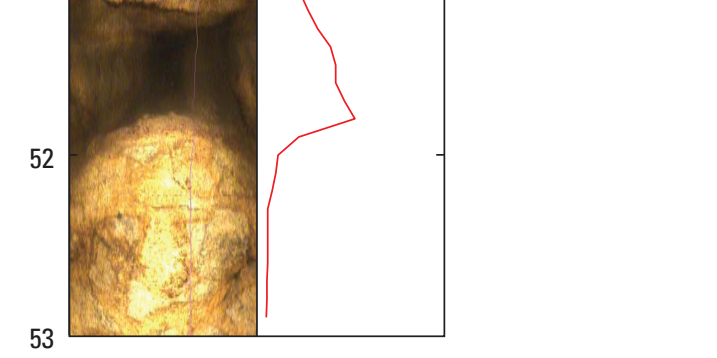

Figure 9. Optical televiewer images of wells (A) PS-100, (B) PS-099, and (C) PS-106 showing typical open fractures in the subsurface granite near the GMH Electronics Superfund site. 


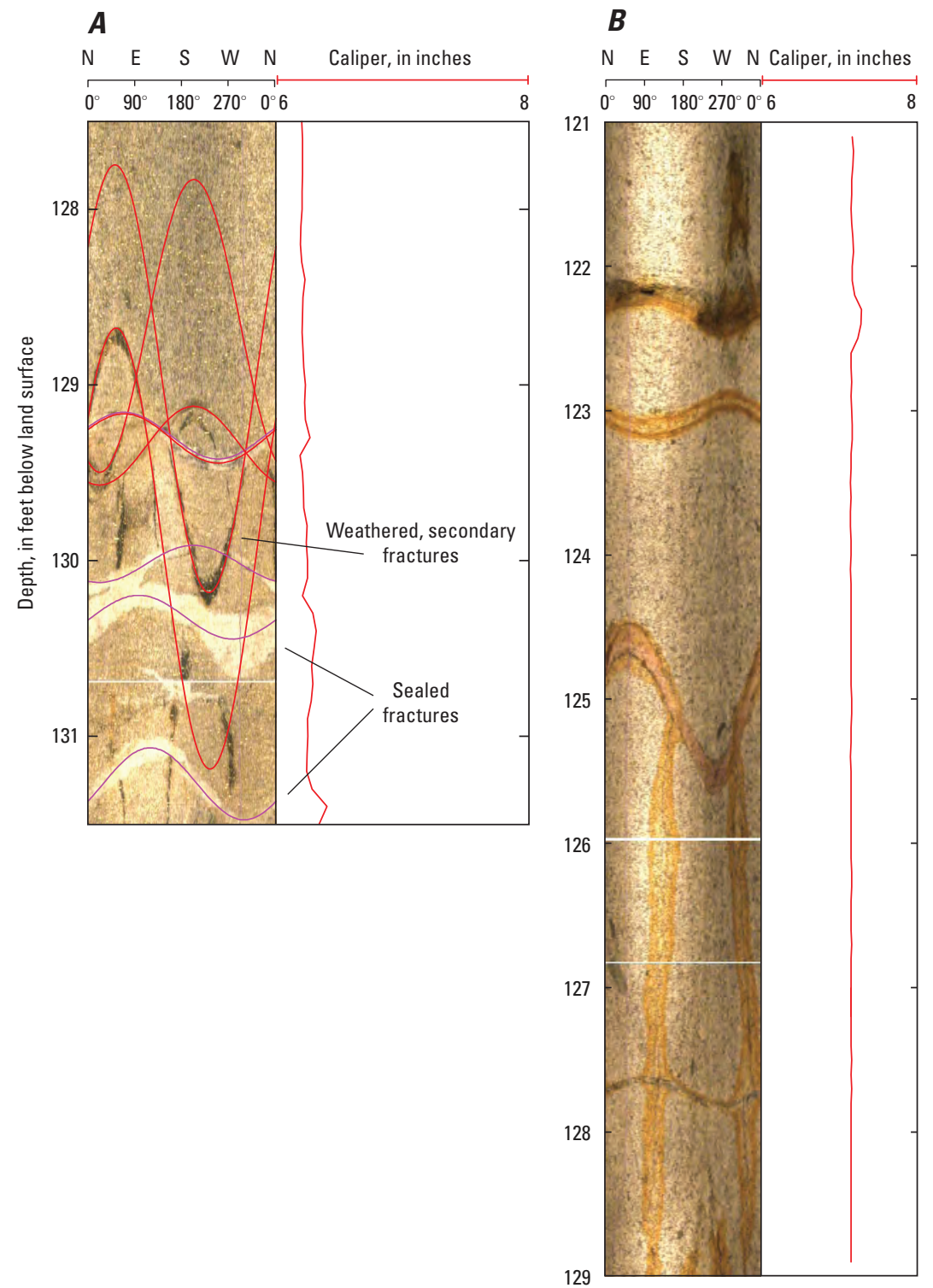

Figure 10. Optical televiewge of $(A)$ secondary weathered and sealed fractures in well PS-105, and (B) typical iron staining along fractures in well PS-103. 


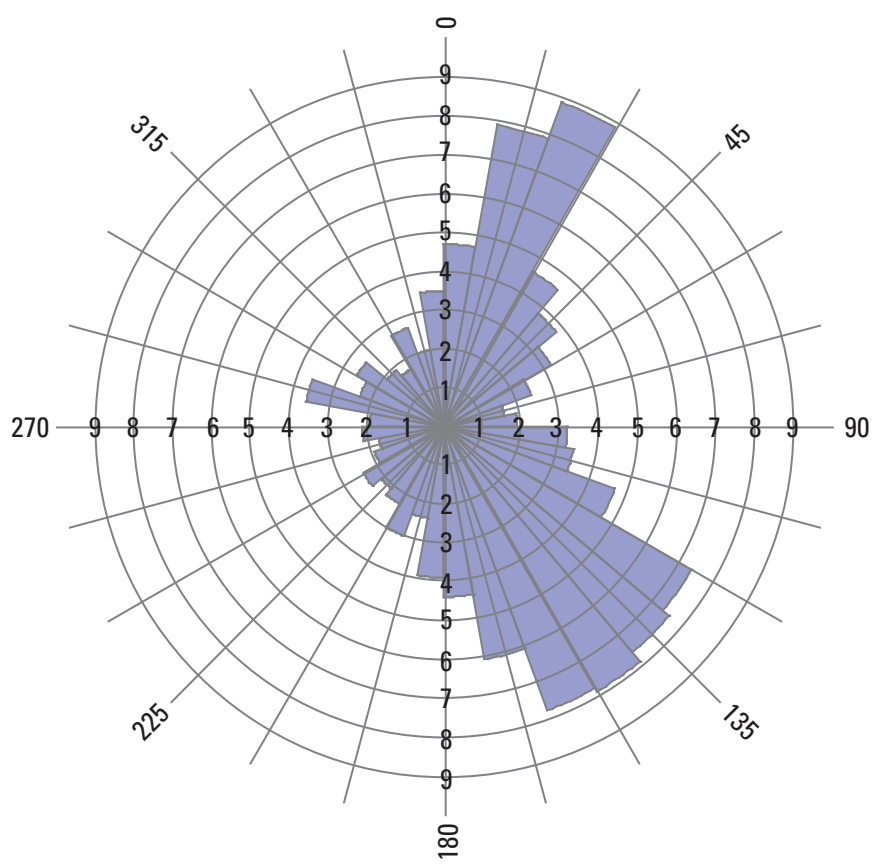

Figure 11. Rose diagram showing all structures measured in the 15 wells logged near the GMH Electronics Superfund site. Length of petal corresponds to percent of the total number of measurements.

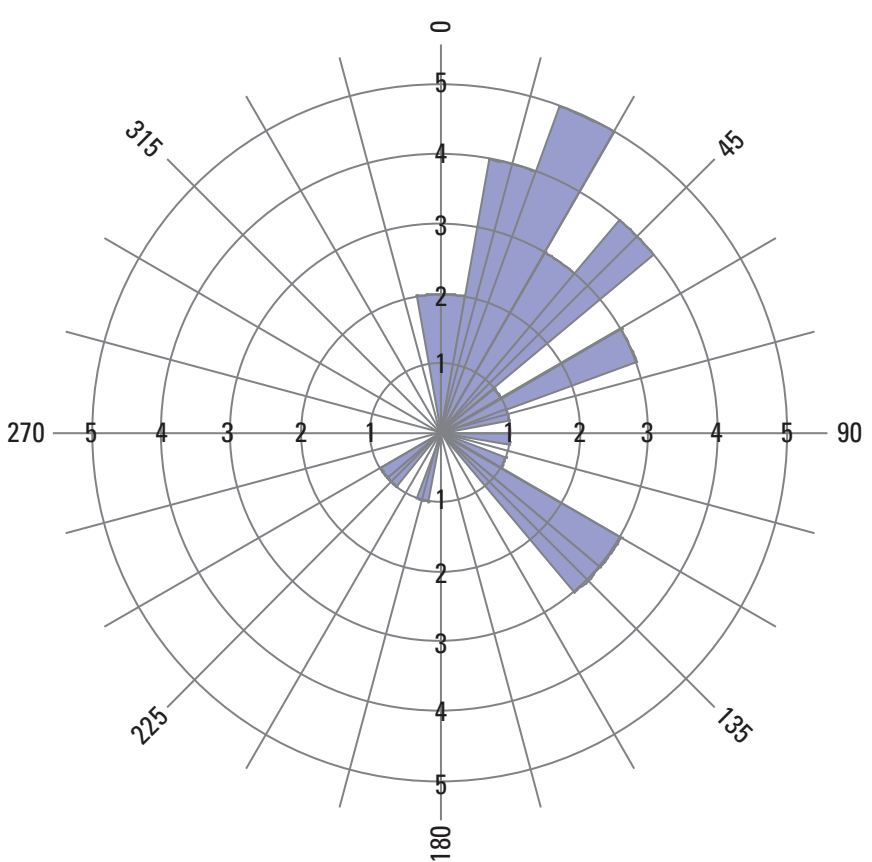

Figure 12. Rose diagram showing strike orientation of subsurface foliation measurements from the 15 wells logged near the GMH Electronics Superfund site. Length of petal corresponds to percent of the total number of measurements.

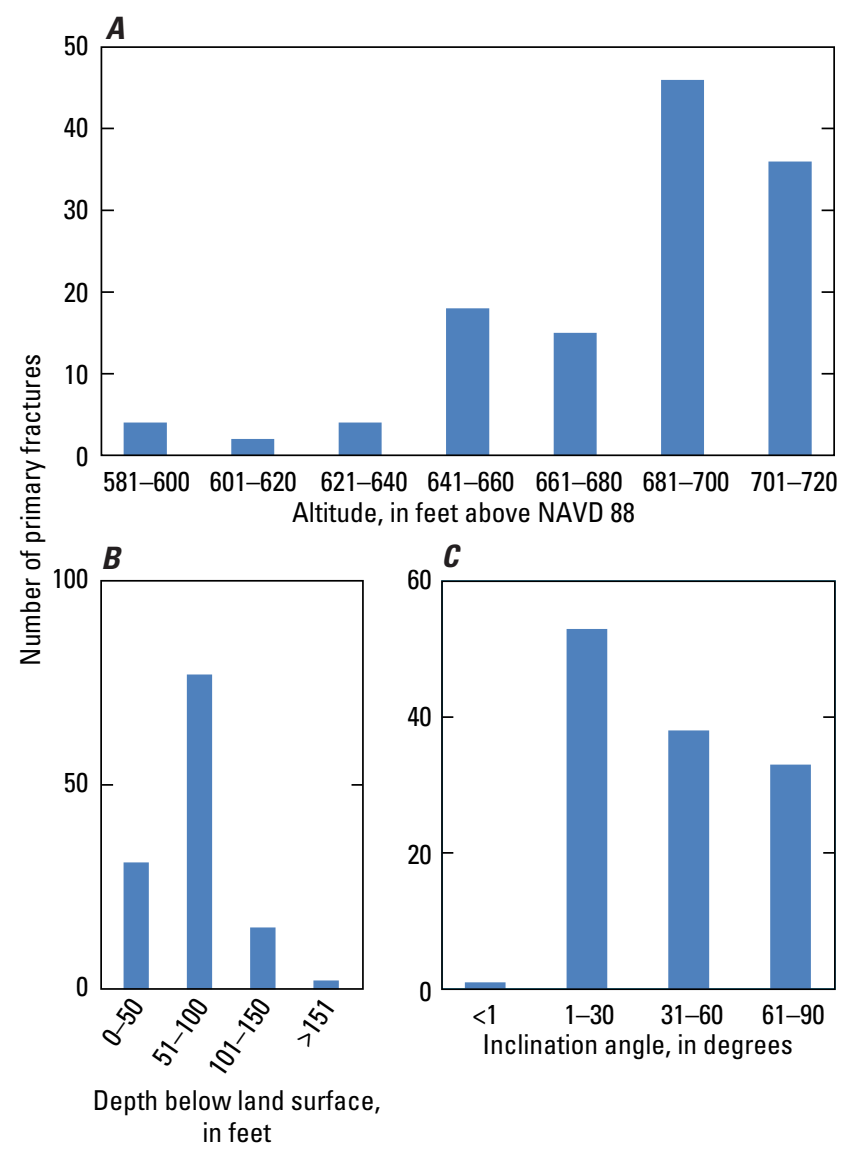

Figure 13. Graphs showing $(A)$ altitude, $(B)$ depth, and $(C)$ inclination angle of primary fractures logged from 15 wells near the GMH Electronics Superfund site.

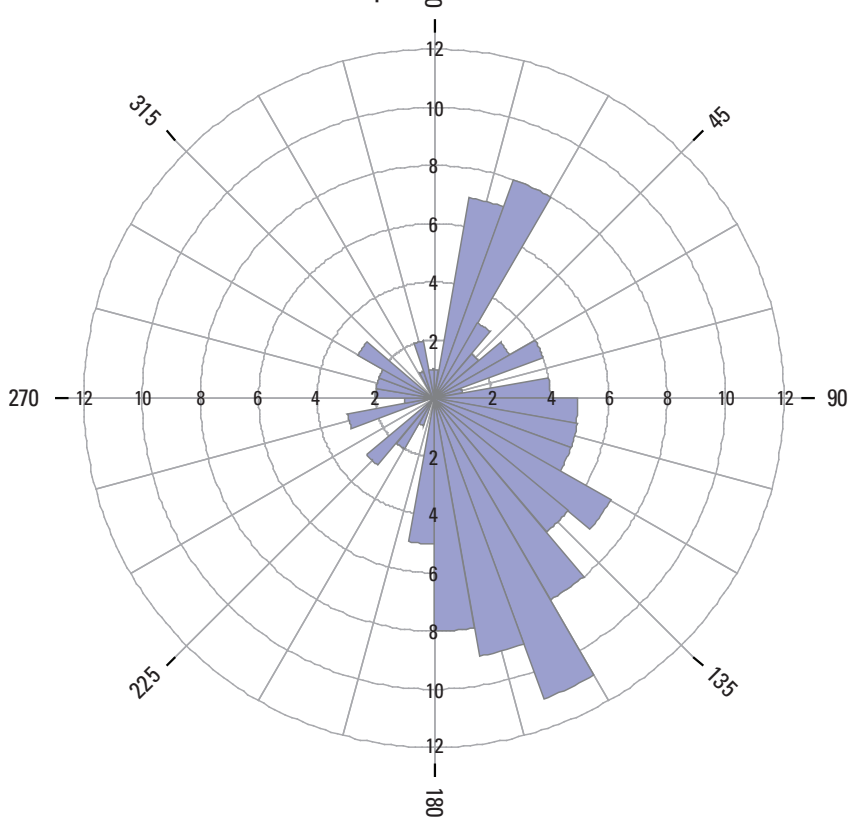

Figure 14. Rose diagram showing dominant orientations of open fractures measured in the 15 open borehole wells from optical and acoustic televiewer images. Length of petal corresponds to percent of the total number of measurements. 


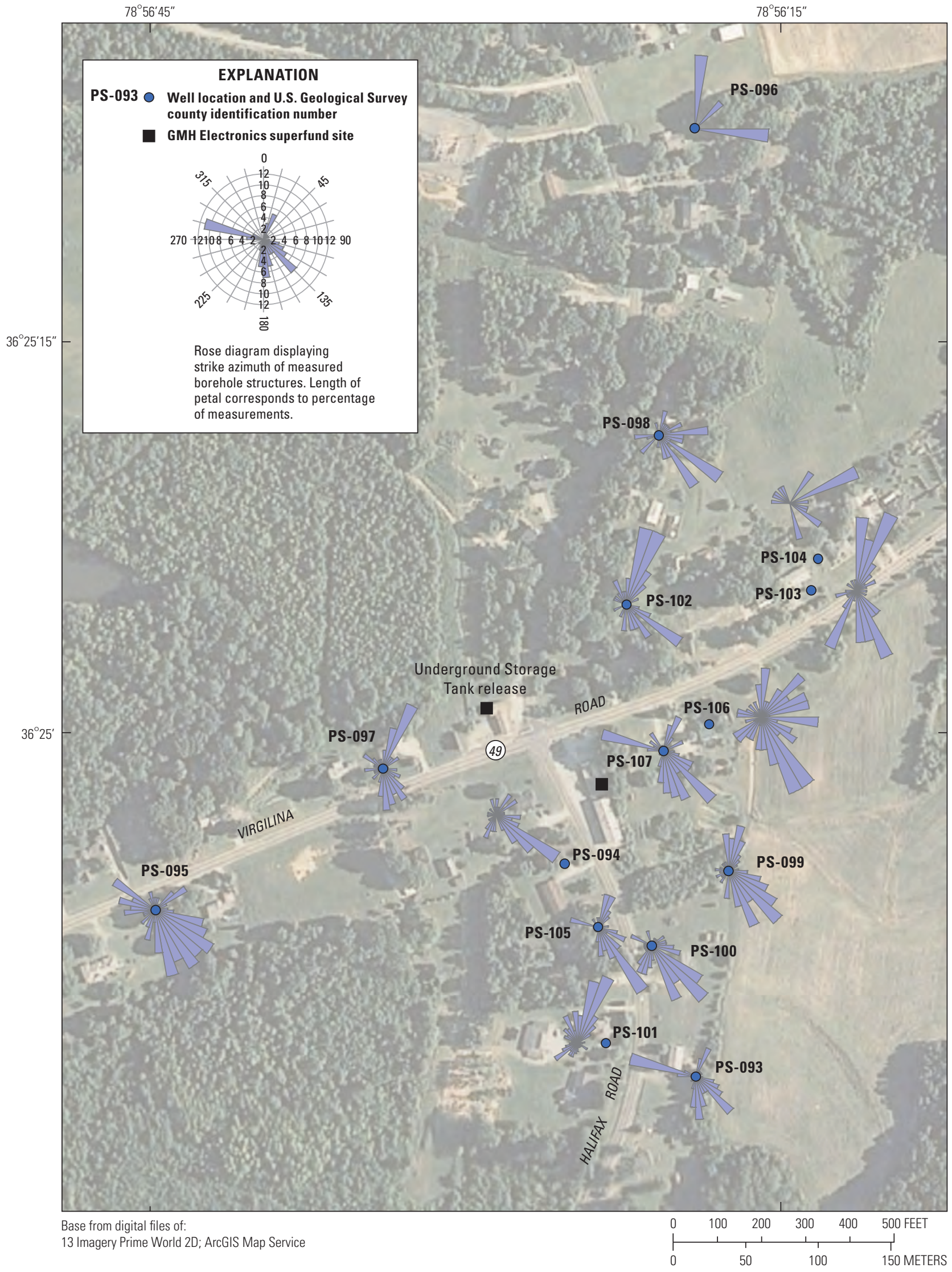

Figure 15. Rose diagram map showing the distribution of subsurface structures measured in 15 open borehole wells from optical and acoustic televiewer images. 


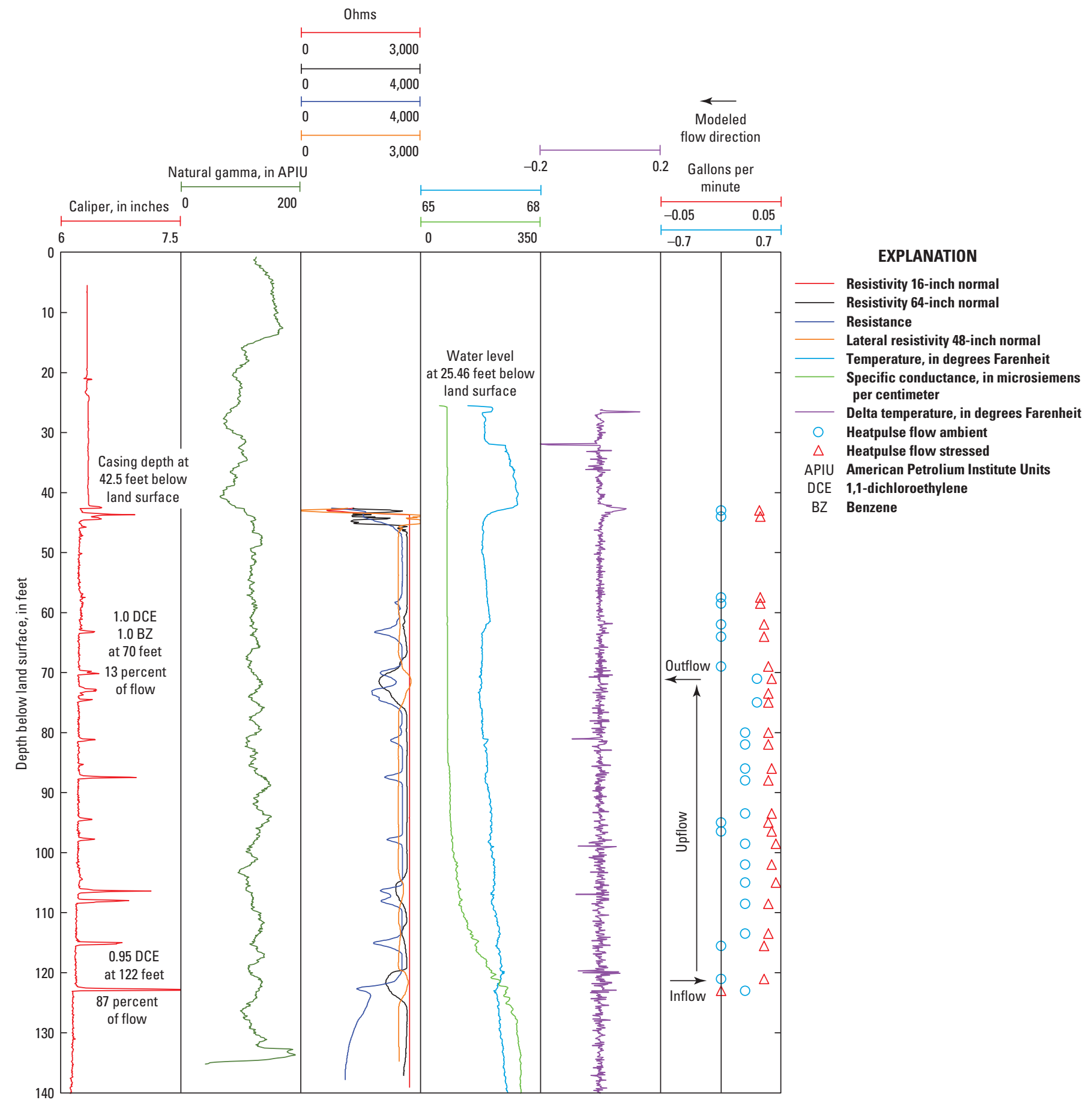

Figure 16. Borehole geophysical logs from well PS-093 showing fracture zones and upward vertical flow at depth. 


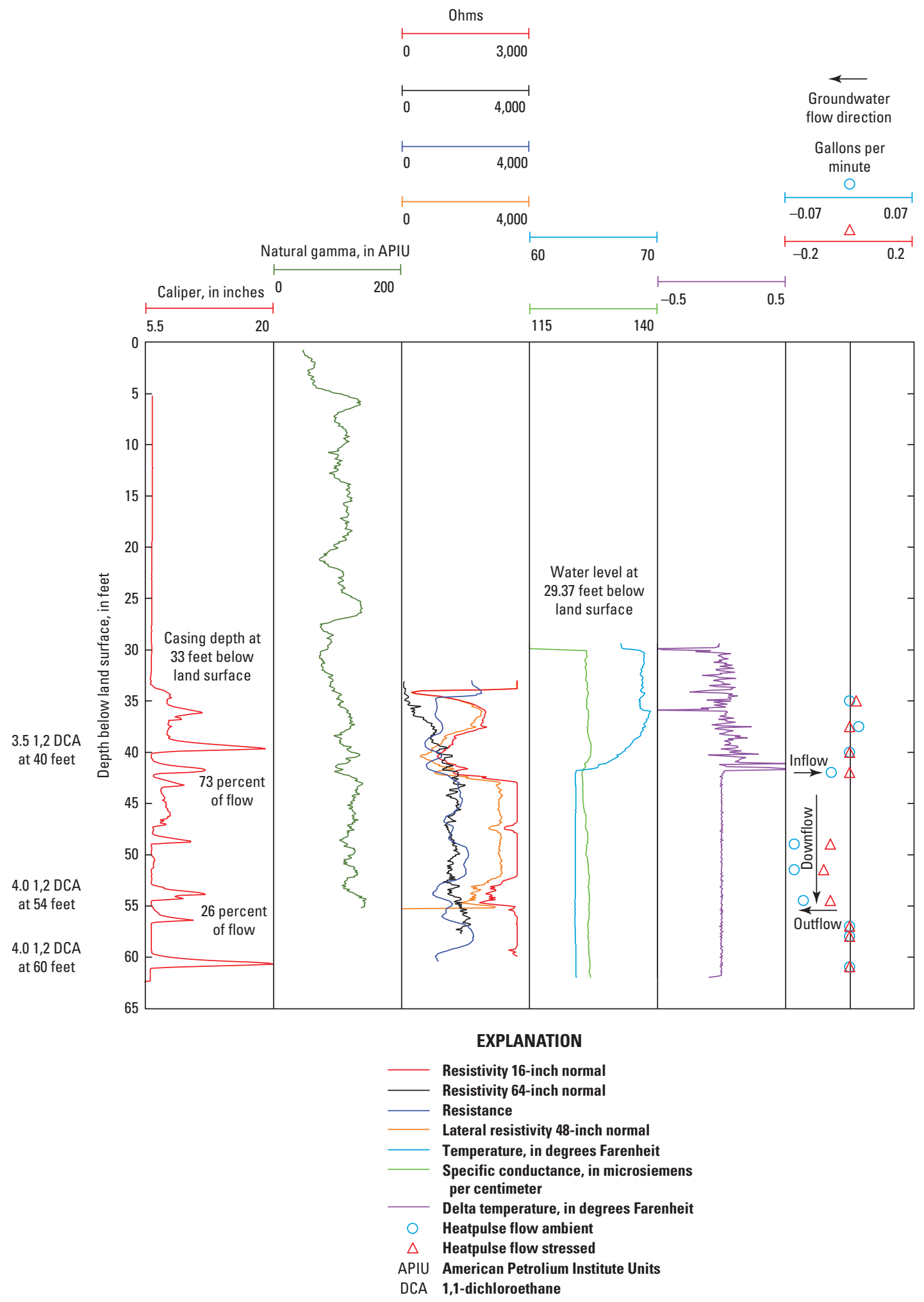

Figure 17. Borehole geophysical logs from well PS-098 showing fracture zones and downward vertical flow at depth. 
arrows in figures 16 and 17 and in appendix 4 reflect modeled (simplified) results shown in appendix 7. For example, flow may have been measured at several fractures; however, FLASH modeling results typically portray only dominant fracture zones, thereby reducing the number of fractures contributing flow. A larger number of contributing fracture zones were initially modeled using FLASH; however, some fracture zones were removed from the model because erroneous hydraulic heads were simulated (for example, 1,000 feet higher head compared to the zone above).

Transmissivity estimates for the 15 wells ranged from 0.41 to 154 feet squared per day $\left(\mathrm{ft}^{2} / \mathrm{d}\right)$, and estimates of the radius of influence ranged from 9.5 to $113 \mathrm{ft}$ (table 3). Initial estimates of transmissivity were made using specific capacity calculations from the stressed heat-pulse flowmeter logs and modeled transmissivity relations for crystalline rocks in southeastern New York (John H. Williams, U.S. Geological Survey, written commun., 2012). The depth of fractures where flow was modeled ranged from 41 to $152 \mathrm{ft}$ below land surface (app. 7).

The three-dimensional diagrams of borehole structures shown in figures 18-21 indicate potential interconnectivity of fracture zones between wells. Fractures having similar dip azimuths and angles are recognized as parallel fracture images. The distribution of subsurface fractures and their associated three-dimensional orientations can potentially control contaminant migration, depending on the location of source areas and hydraulic head distributions between fracture zones.

Table 3. FLASH program modeling results for heat-pulse flowmeter logs collected from the fifteen wells near the GMH Electronics Superfund site.

[ $\mathrm{ft}^{2} / \mathrm{d}$; foot squared per day; $\mathrm{ft}$, foot; gpm, gallon per minute; na, not available]

\begin{tabular}{cccc}
\hline Well & $\begin{array}{c}\text { Transmissivity } \\
\text { (ft } \mathbf{2} / \mathbf{d})\end{array}$ & $\begin{array}{c}\text { Radius of } \\
\text { influence } \\
\text { (ft) }\end{array}$ & $\begin{array}{c}\text { Yield } \\
\text { reported } \\
\text { (gpm) }\end{array}$ \\
\hline PS-093 & 22 & 23 & 15 \\
PS-094 & 20 & 22 & 8 \\
PS-095 & 2.6 & 24 & 1 \\
PS-096 & 15 & 23 & na \\
PS-097 & 7.1 & 13 & 3 \\
PS-098 & 154 & 24 & 10 \\
PS-099 & 12 & 113 & 10 \\
PS-100 & 135 & 25 & 10 \\
PS-101 & 1.7 & 22 & na \\
PS-102 & 41 & 24 & na \\
PS-103 & 0.41 & 9.5 & na \\
PS-104 & 28 & 24 & na \\
PS-105 & 2.3 & 17 & 7 \\
PS-106 & 133 & 24 & 15 \\
PS-107 & 35 & 25 & na \\
\hline
\end{tabular}

\section{Sampling Biases Inherent in the Borehole Surveys and the Surface Outcrop Measurements}

Cursory inspection of the borehole structural data tables and diagrams in this report and the surface geologic structural data show differences in their relative abundances of planar features counted within the various general orientation classes. This does not mean that the two sets of data are inconsistent with each other, but rather that the two data sets are more useful when used together. Vertical boreholes are statistically less likely to intersect steeply dipping planar features than more flat-lying features, whereas surface outcrops provide a relatively better sample of more steeply dipping features. With the exception of the rare steep cliff face or high roadcut, outcrops provide relatively less opportunity to count and measure flat-lying features than vertical boreholes (Chapman and Huffman (2011).

Another difference is in the way features were tabulated in the two data sets. When interpreting features in borehole images, hydrogeologists measure and count individual features. During surface mapping, geologists assign measurements to sets of features having a similar orientation. For any given map station, which may represent an entire outcrop or group of outcrops, one recorded measurement could represent a group of 1,10 , or 100 parallel similar joints or foliations (Chapman and Huffman, 2011). 


\section{Southwest}

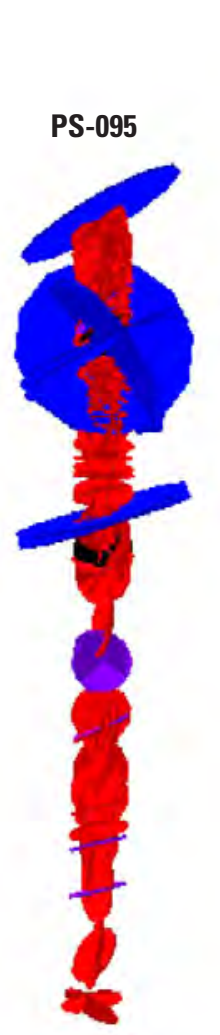

Northeast
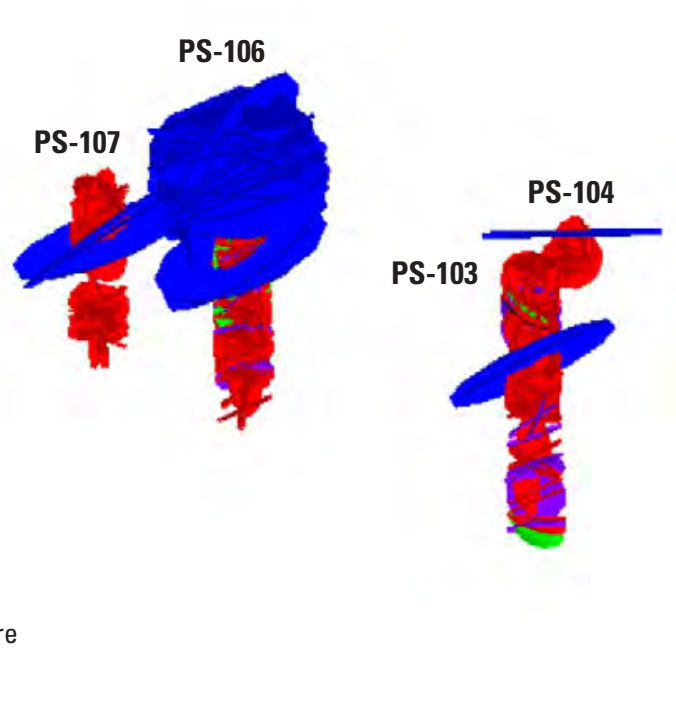

EXPLANATION

$\begin{array}{cl}\text { Blue } & \text { Primary fracture } \\ \text { Red } & \text { Secondary fracture } \\ \text { Green } & \text { Foliation } \\ \text { Purple } & \text { Scaled fractures }\end{array}$

Figure 18. Southwest-to-northeast three-dimensional diagram showing subsurface structures in selected wells. 


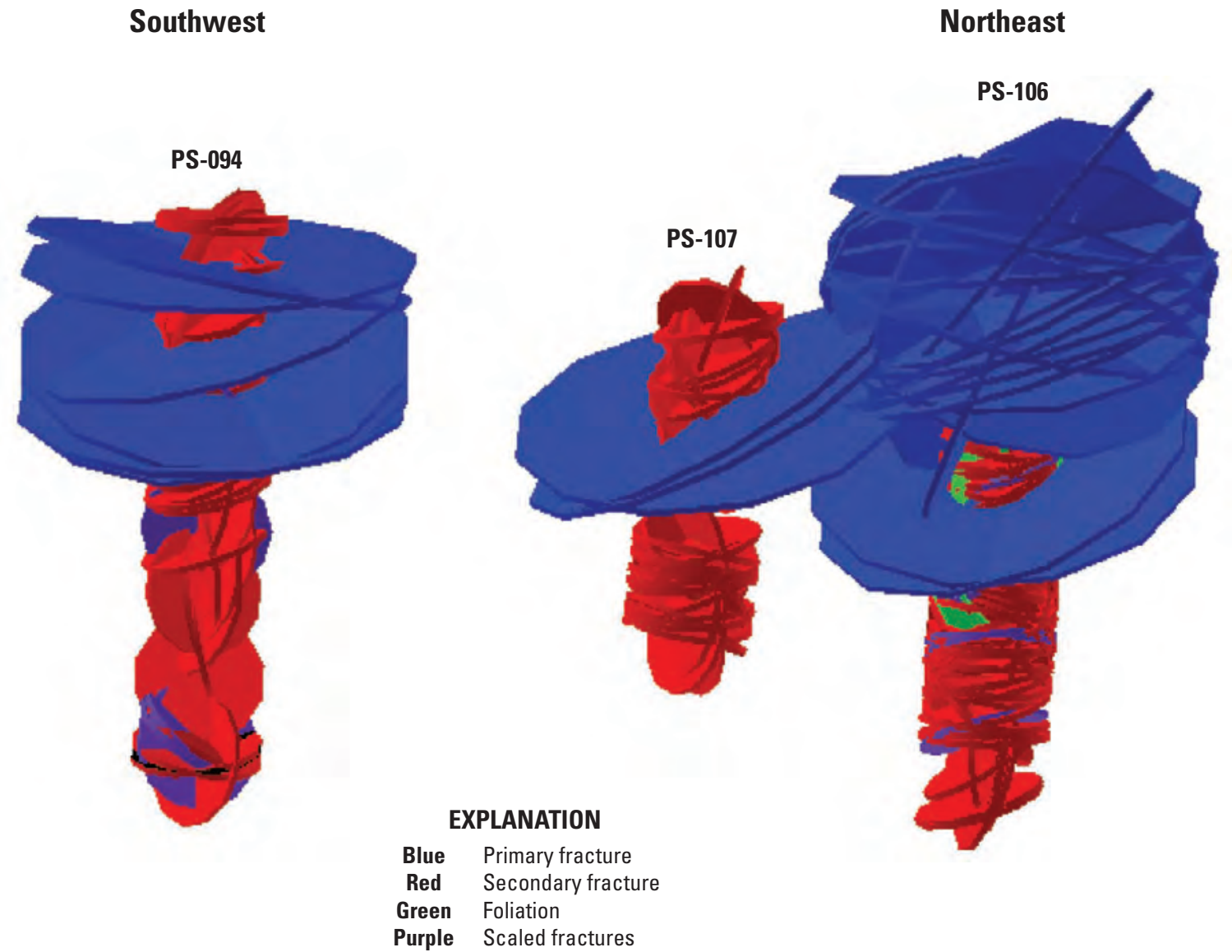

Figure 19. Southwest-to-northeast three-dimensional diagram showing subsurface structures in selected wells.

PS-096

PS-098

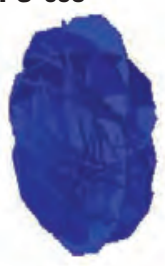

PS-102

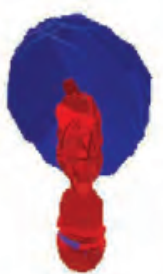

EXPLANATION

Blue Primary fracture

Red Secondary fracture

Green Foliation

Purple Scaled fractures
PS-106
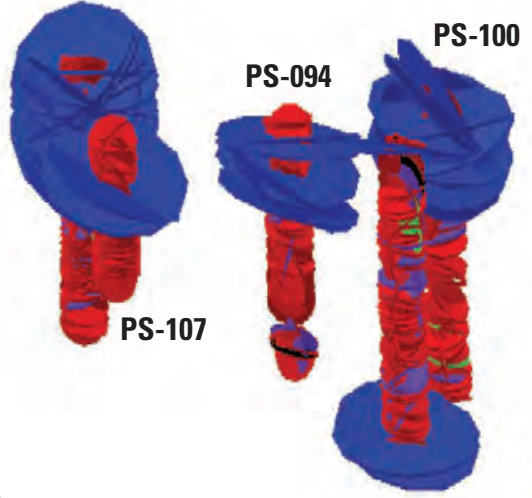

PS-105

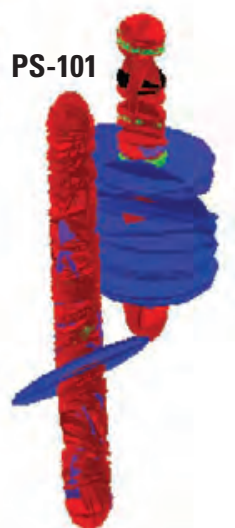

Figure 20. North-to-south three-dimensional diagram showing subsurface structures in selected wells. 


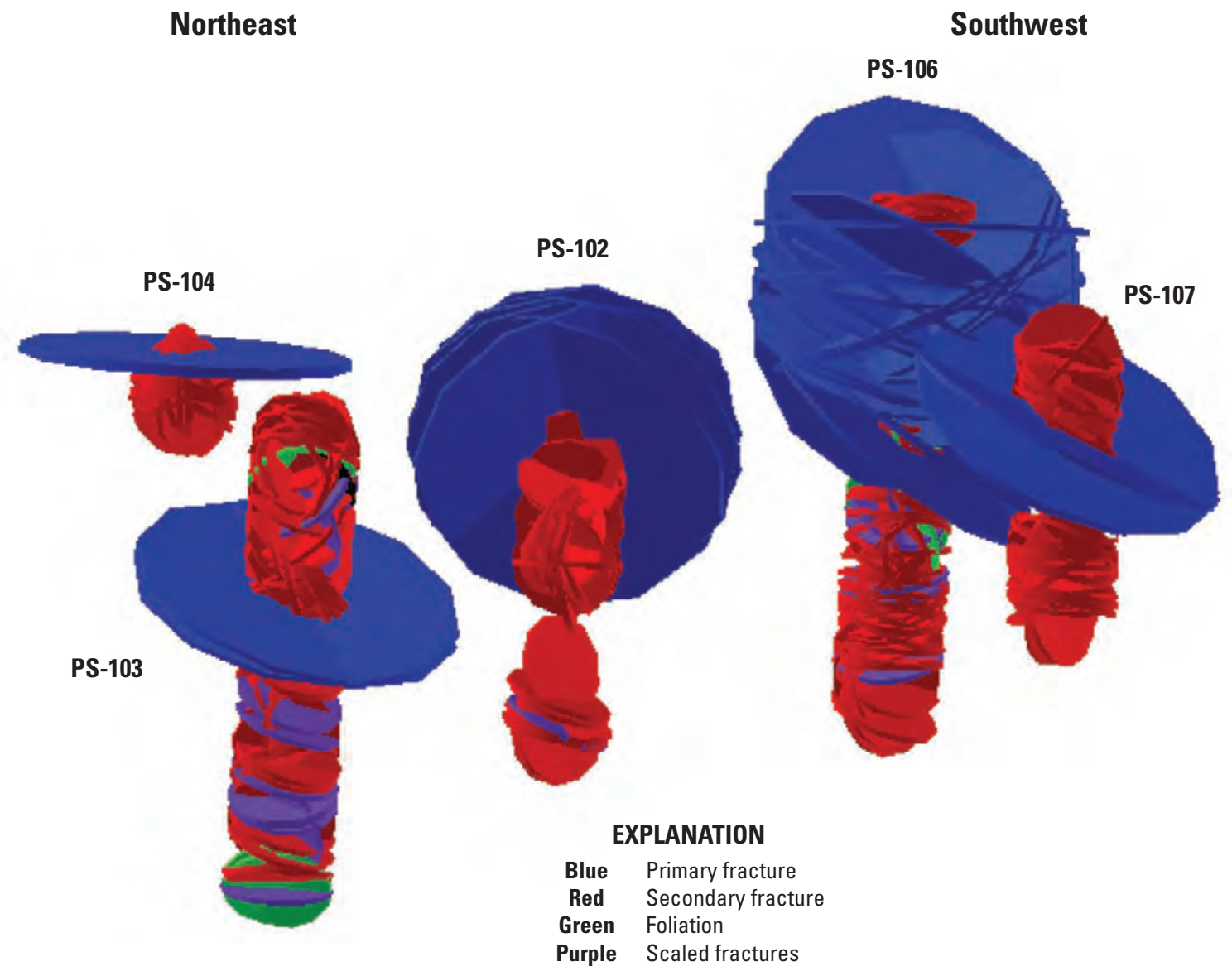

Figure 21. North-to-south three-dimensional diagram showing subsurface structures in selected wells.

\section{Passive Diffusion Bag Sampling Results}

Contaminants detected by the PDB sampling include 1,1,1-trichloroethane (TCA), 1,1-dichloroethane (DCA), 1,1-dichloroethylene (DCE), benzene, o-xylene, cyclohexane, isopropylbenzene, 1,2-dichloroethane, and methyl-tert-butylether. Acetone was detected in the trip blank sample and in several PDB well samples, but is not a known contaminant in the area (app. 8). The manufacturer of the PDBs prepared them pre-filled with deionized water and had a known problem with acetone (Kris McSwain, U.S. Geological Survey, written commun., 2011). Methyl ethyl keytone also was detected in the trip blank, but not in any of the PDB well samples analyzed. Detected concentrations were as high as $1,600 \mu \mathrm{g} / \mathrm{L}$ DCE and $400 \mu \mathrm{g} / \mathrm{L}$ TCA in well PS-106, and 2,300 $\mu \mathrm{g} / \mathrm{L}$ benzene in well PS-102. Depths of detected contaminants ranged from 39 to $276 \mathrm{ft}$ below land surface (app. 8). Figures 22-24 show the areal distribution of DCE, TCA, and benzene detected from the PDB sampling as part of this study.

\section{Hydrogeologic and Water-Quality Sections}

Two 2-dimensional cross-sections were constructed parallel to Virgilinia and Halifax Roads, oriented and S. $64^{\circ}$ W. to N. $64^{\circ}$ E., and North-South, respectively $\left(A-A^{\prime}, B-B^{\prime}\right.$; figs. 2, 25 and 26) to display both collected surface geologic structural data and the subsurface fracture orientation data. Geologic structural features were generalized in both cross sections using a $30^{\circ}$ orientation for foliation, and displaying 1 low-angle joint set having a strike orientation of $150^{\circ}$ and dip angle of $21^{\circ}$, and 3 steeply dipping sets having strike orientations of $-20^{\circ}, 120^{\circ}$, and $210^{\circ}$, and a dip angle of $78^{\circ}$. Borehole fracture sets are shown at the depths where PDB samples were collected. All dip angles of surface geologic features and borehole fractures were adjusted to the respective cross-section plane orientation. The distribution of 1,1 dichloroethylene (DCE) and 1,1,1 trichloroethane (TCA) with depth is shown in figures 27 and 28 and the distribution of benzene with depth is shown in figures 29 and 30 along the same cross-sections, $A-A^{\prime}$ and $B-B^{\prime}$, used for figures 25 and 26. 


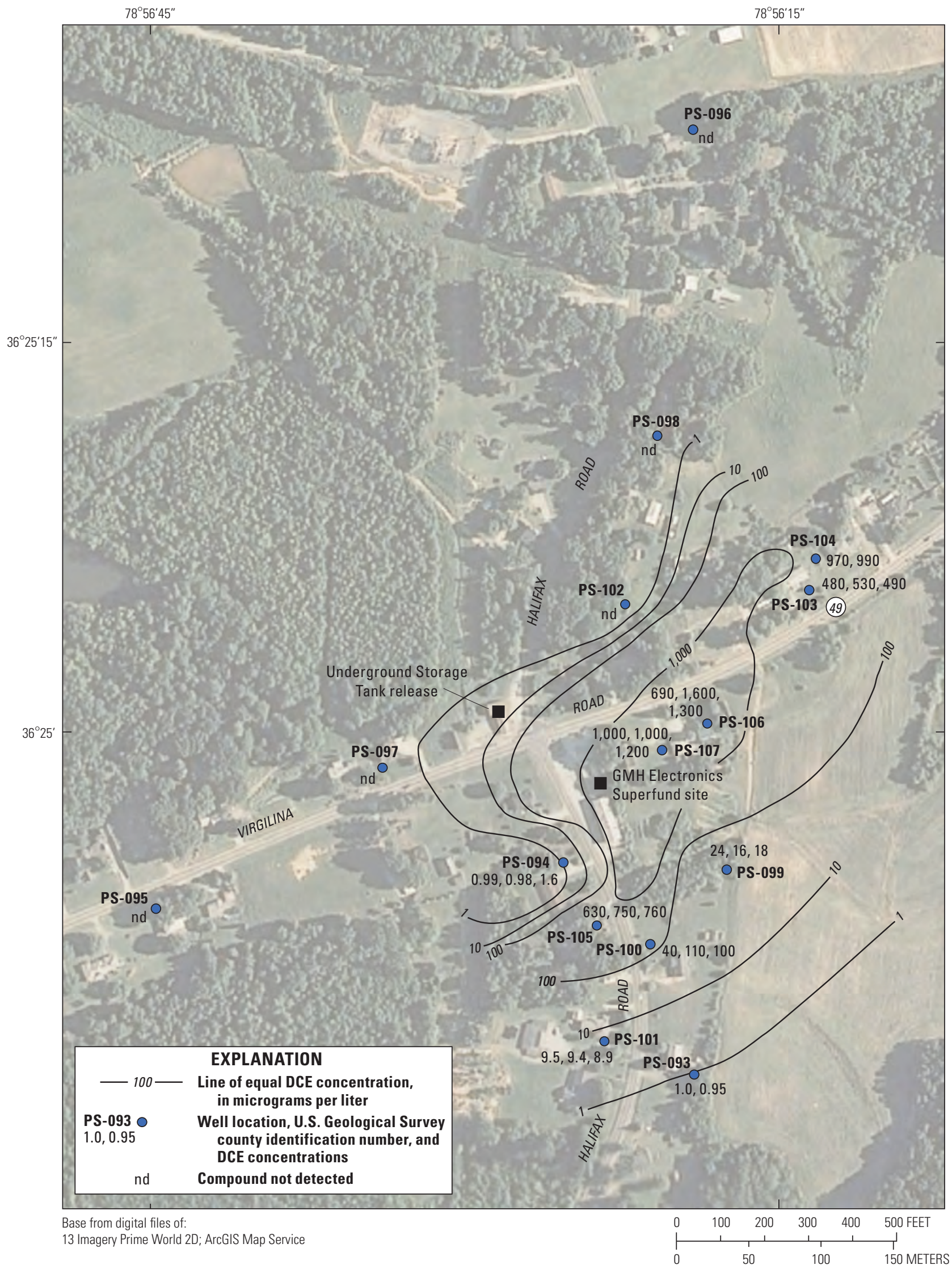

Figure 22. Map showing distribution of 1,1 dichloroethylene (DCE) concentrations detected in passive diffusion bag samples collected in wells near the GMH Electronic Superfund site during September 12 through October 3-4, 2011. 


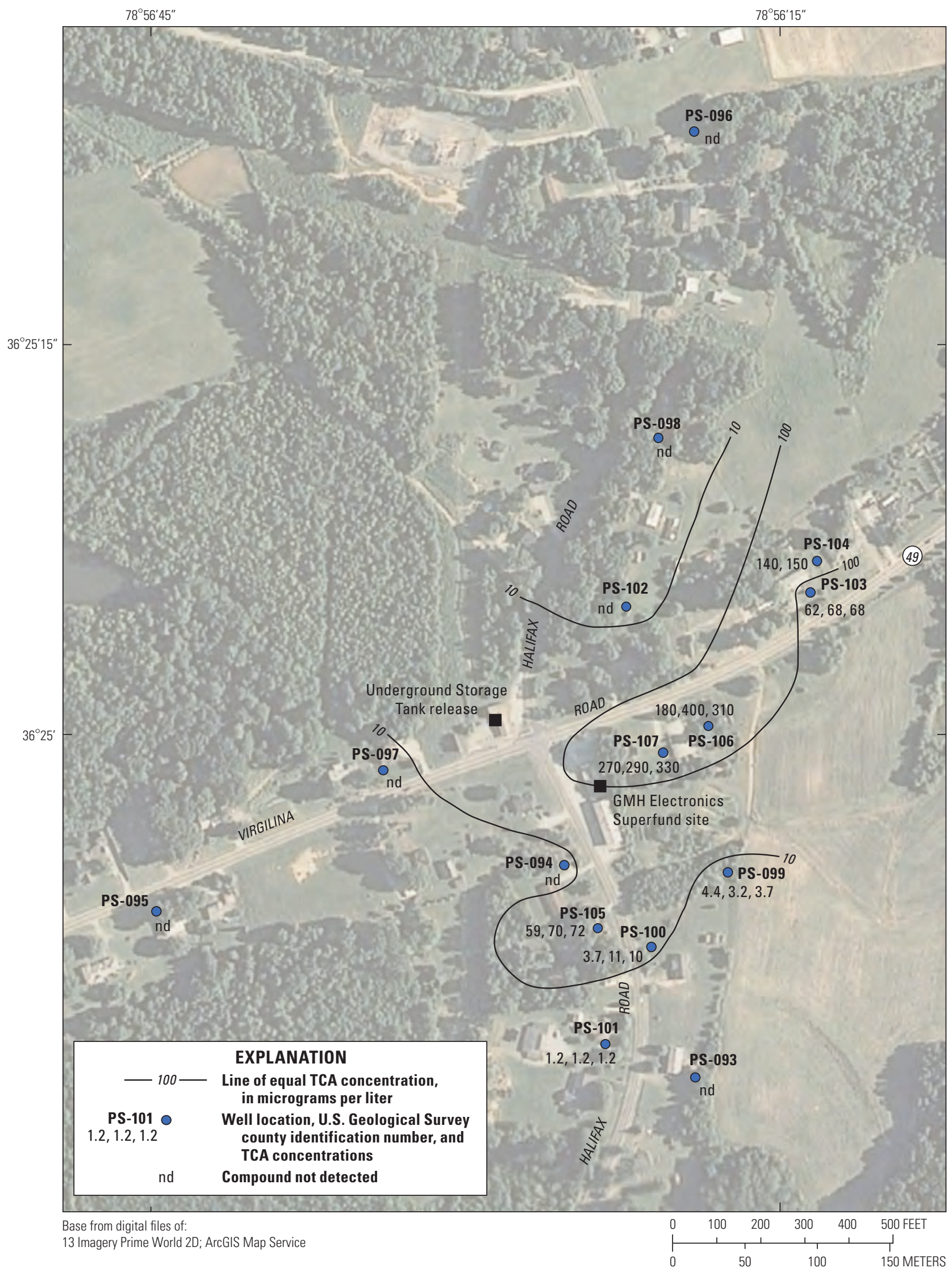

Figure 23. Map showing distribution of 1,1,1 trichloroethane (TCA) concentrations detected in passive diffusion bag samples collected in wells near the GMH Electronic Superfund site during September 12 through 0ctober 3-4, 2011. 


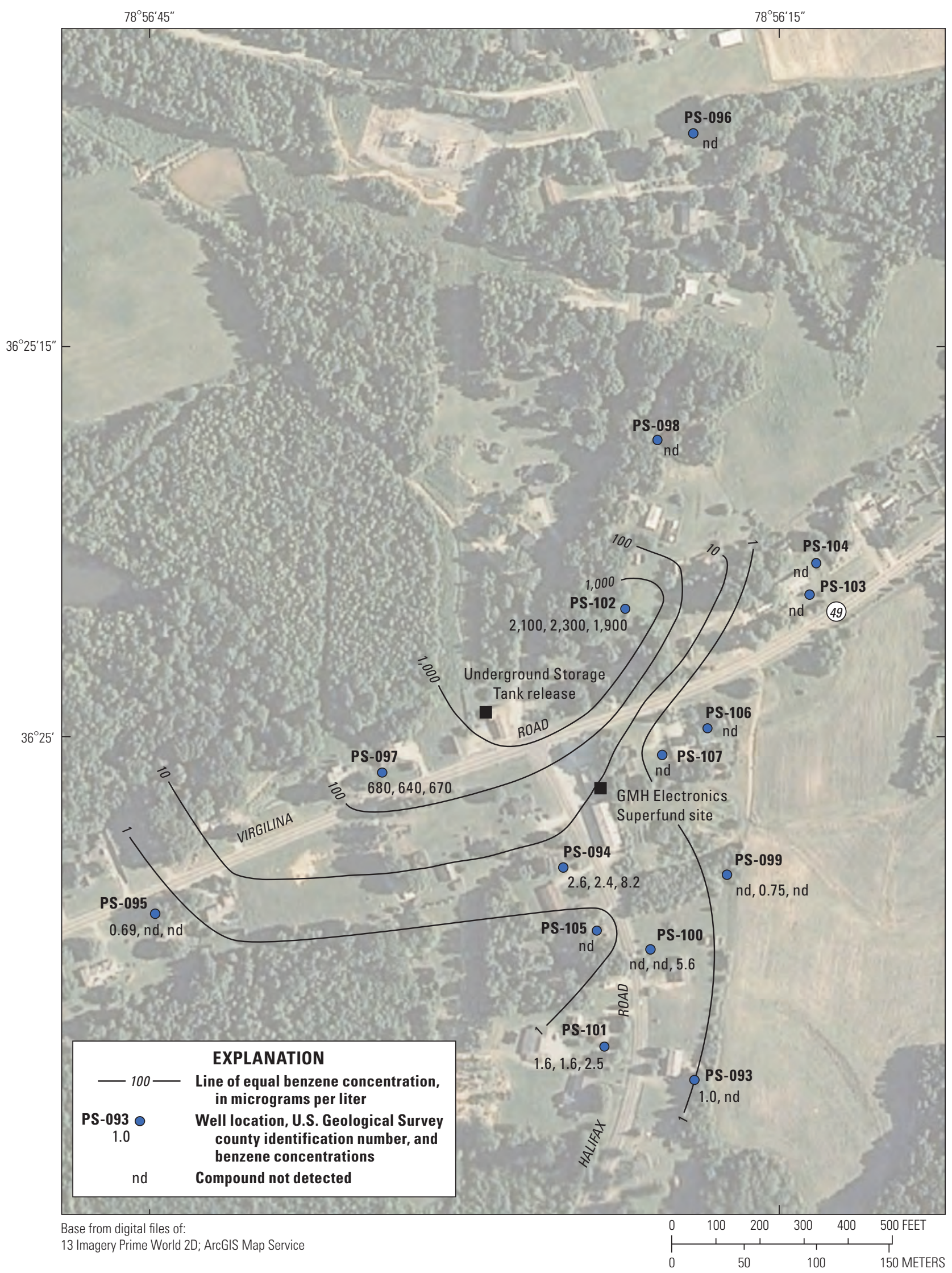

Figure 24. Map showing distribution of benzene concentrations detected in passive diffusion bag samples collected in wells near the GMH Electronic Superfund site during September 12 through October 3-4, 2011. 


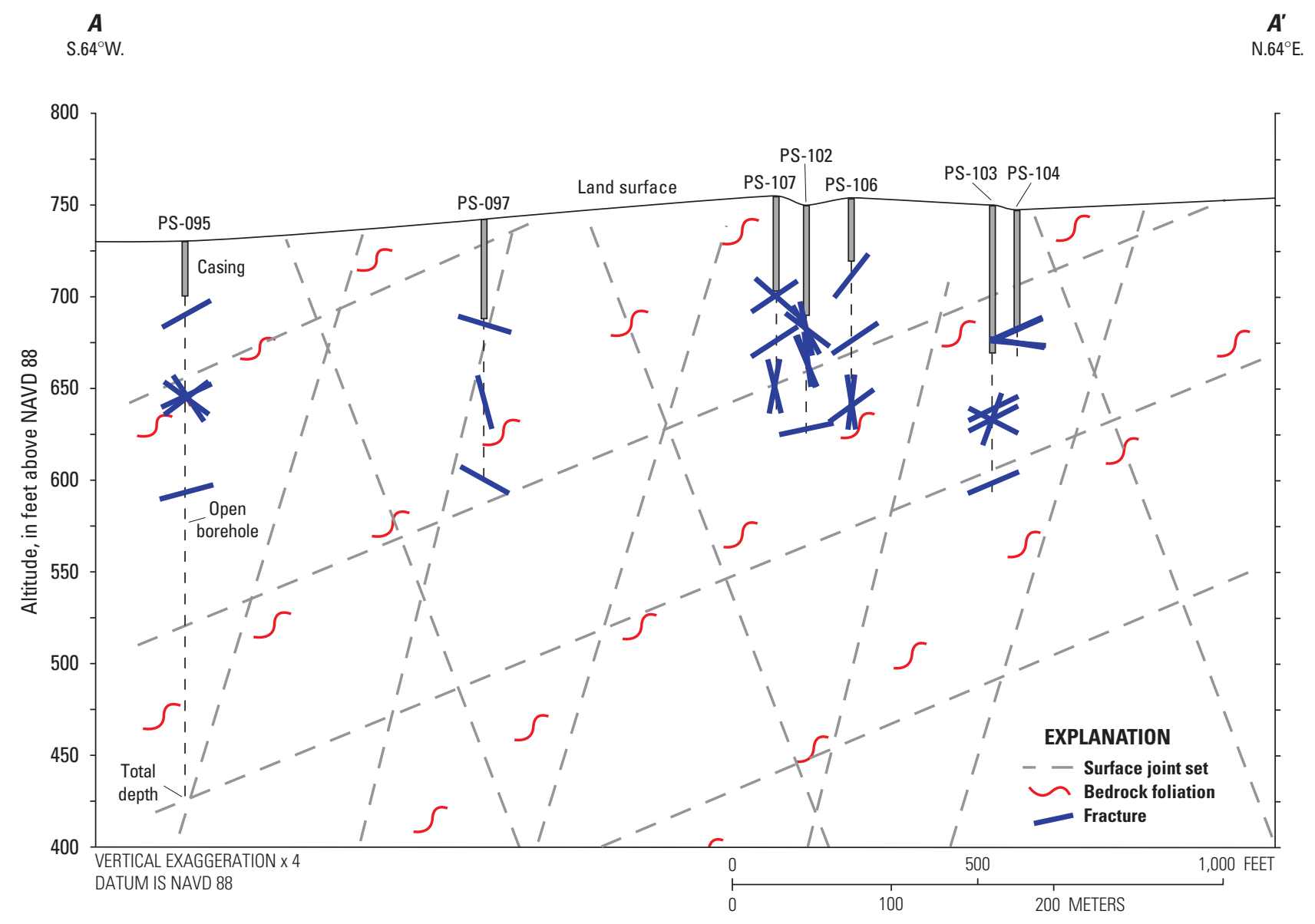

Figure 25. Schematic cross section $A-A$ ' showing depths to and orientations of subsurface borehole fractures and generalized orientation of surface geologic structural features. Line of section shown on fig. 2. 


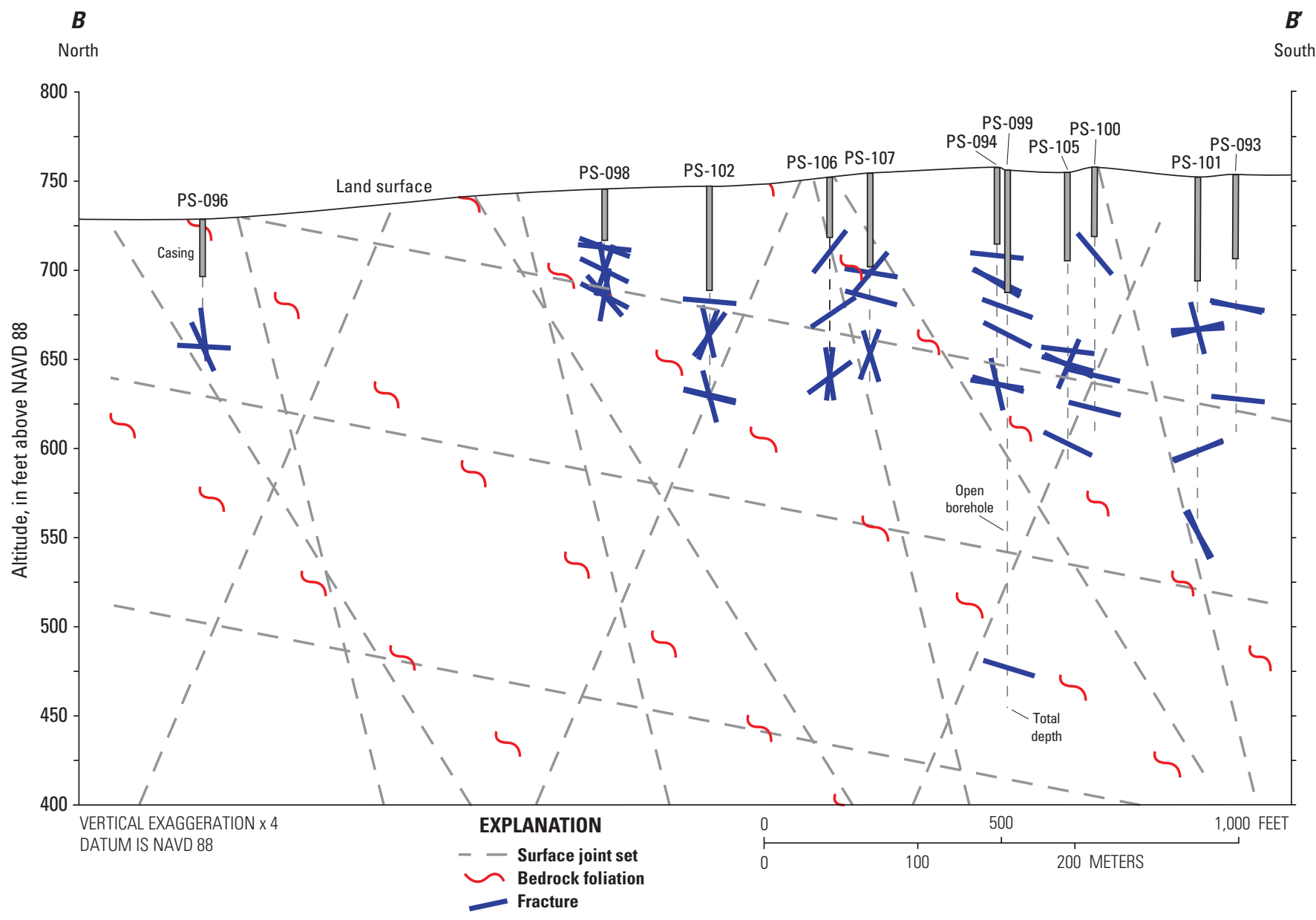

Figure 26. Schematic cross section $B-B^{\prime}$ showing depths to and orientations of subsurface borehole fractures and generalized orientation of surface geologic structural features. Line of section shown on fig. 2. 
$\boldsymbol{A}$

$\mathrm{S} .64^{\circ} \mathrm{W}$.

N.64ㄷ.

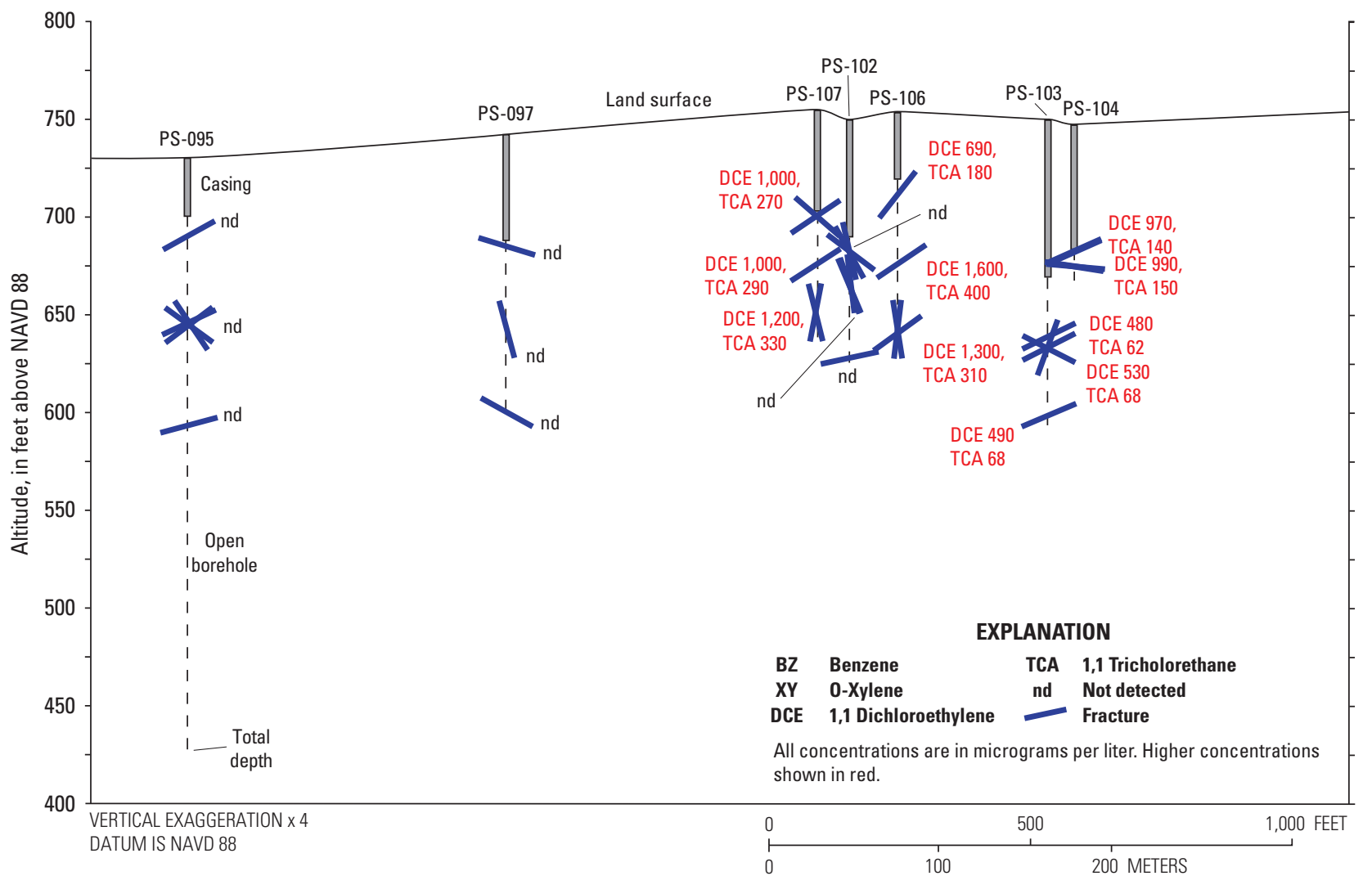

Figure 27. Schematic cross section $A-A$ ' showing depths to and orientations of borehole fractures and detected 1,1 dichloroethylene (DCE) and 1,1,1 trichloroethane (TCA) concentrations from the passive diffusion bag sampling during October 2011. Line of section shown on fig. 2. 


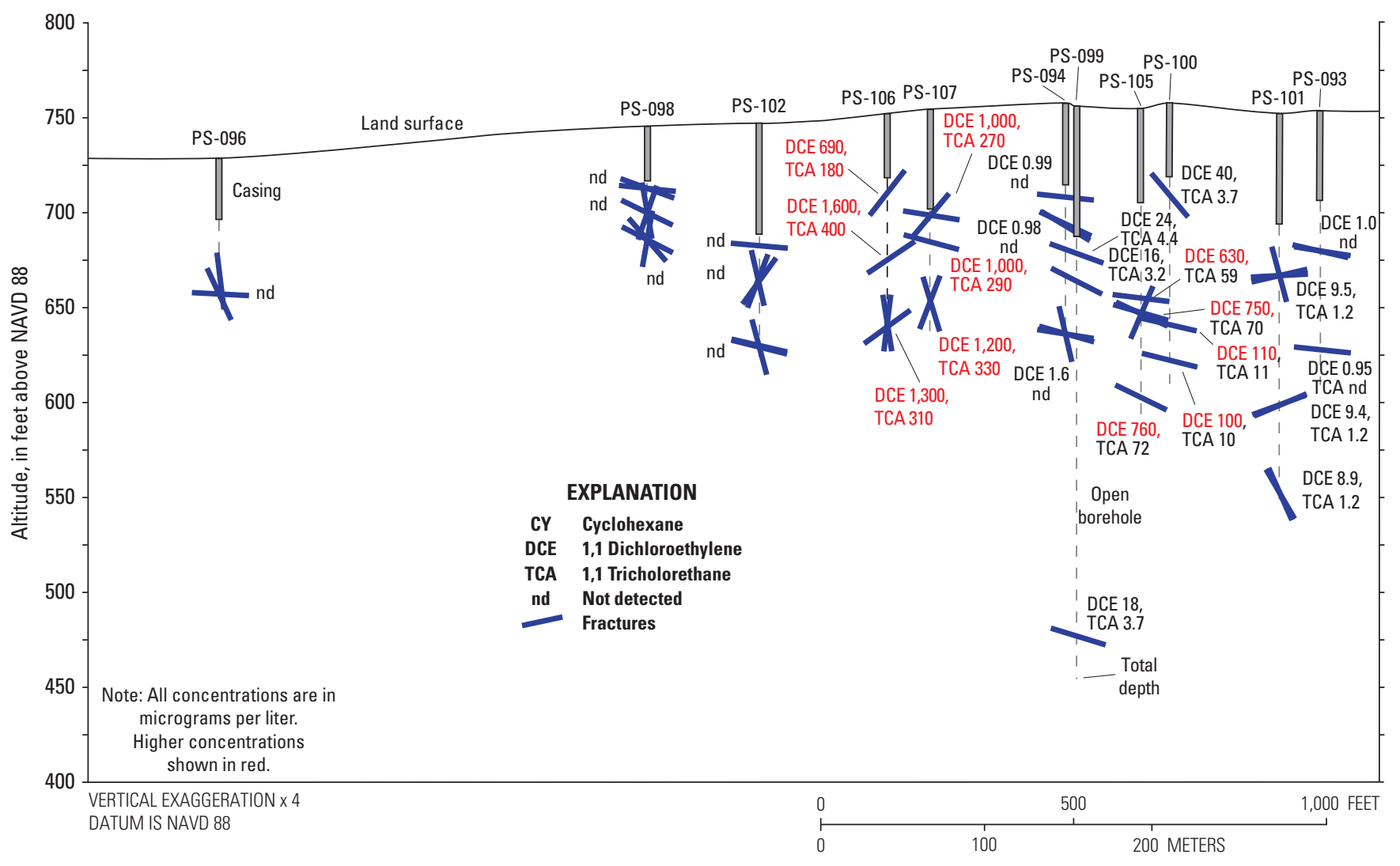

Figure 28. Schematic cross section $B-B^{\prime}$ showing depths to and orientations of borehole fractures and detected 1,1 dichloroethylene (DCE) and 1,1,1 trichloroethane (TCA) concentrations from the passive diffusion bag samping during October 2011. Line of section shown on fig. 2. 
A

S. $64^{\circ} \mathrm{W}$.

N. $64^{\circ} \mathrm{E}$.

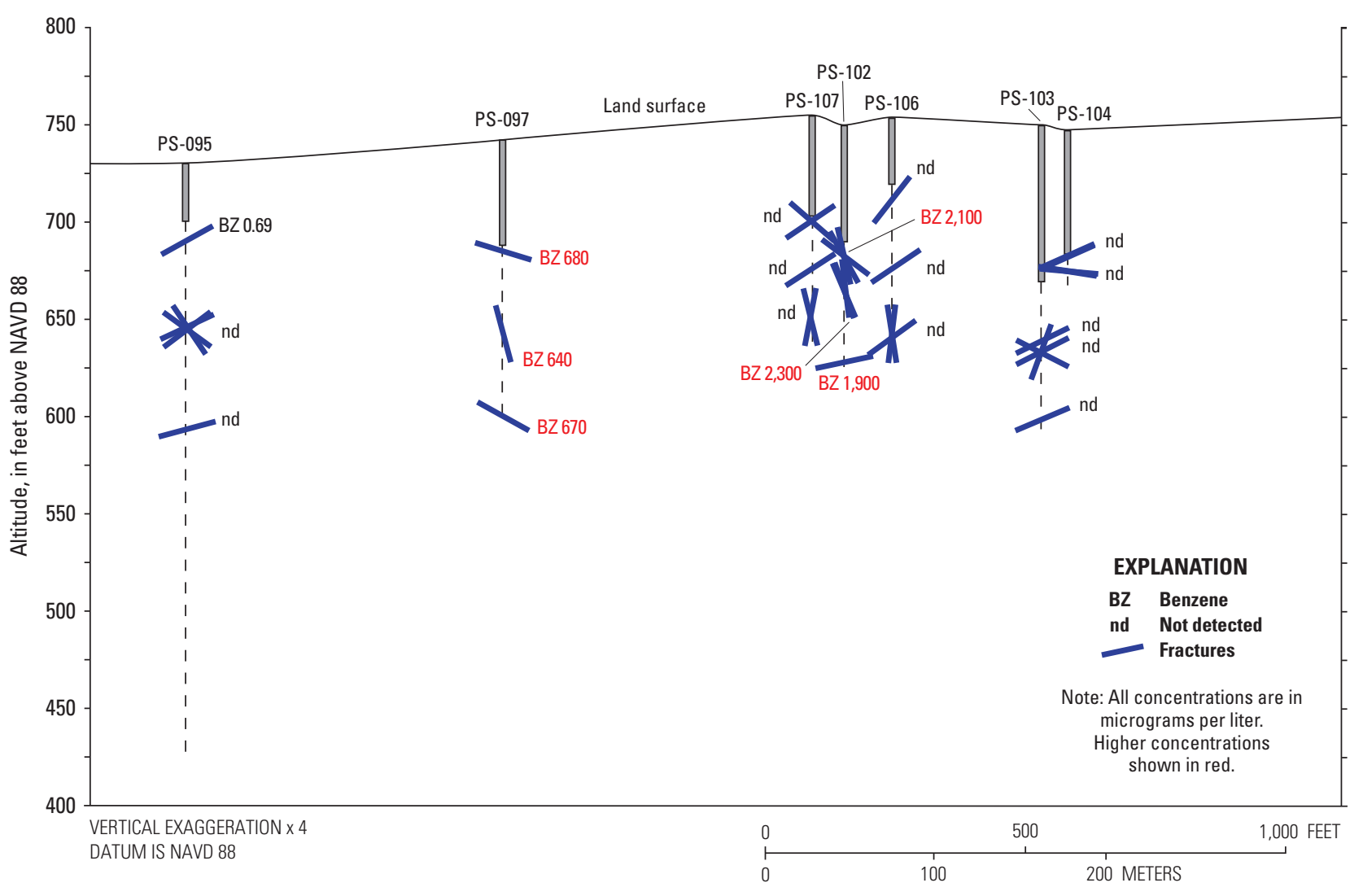

Figure 29. Schematic cross section $A-A$ ' showing depths to and orientations of borehole fractures and detected benzene concentrations from the passive diffusion bag sampling during October 2011. Line of section shown on fig. 2. 


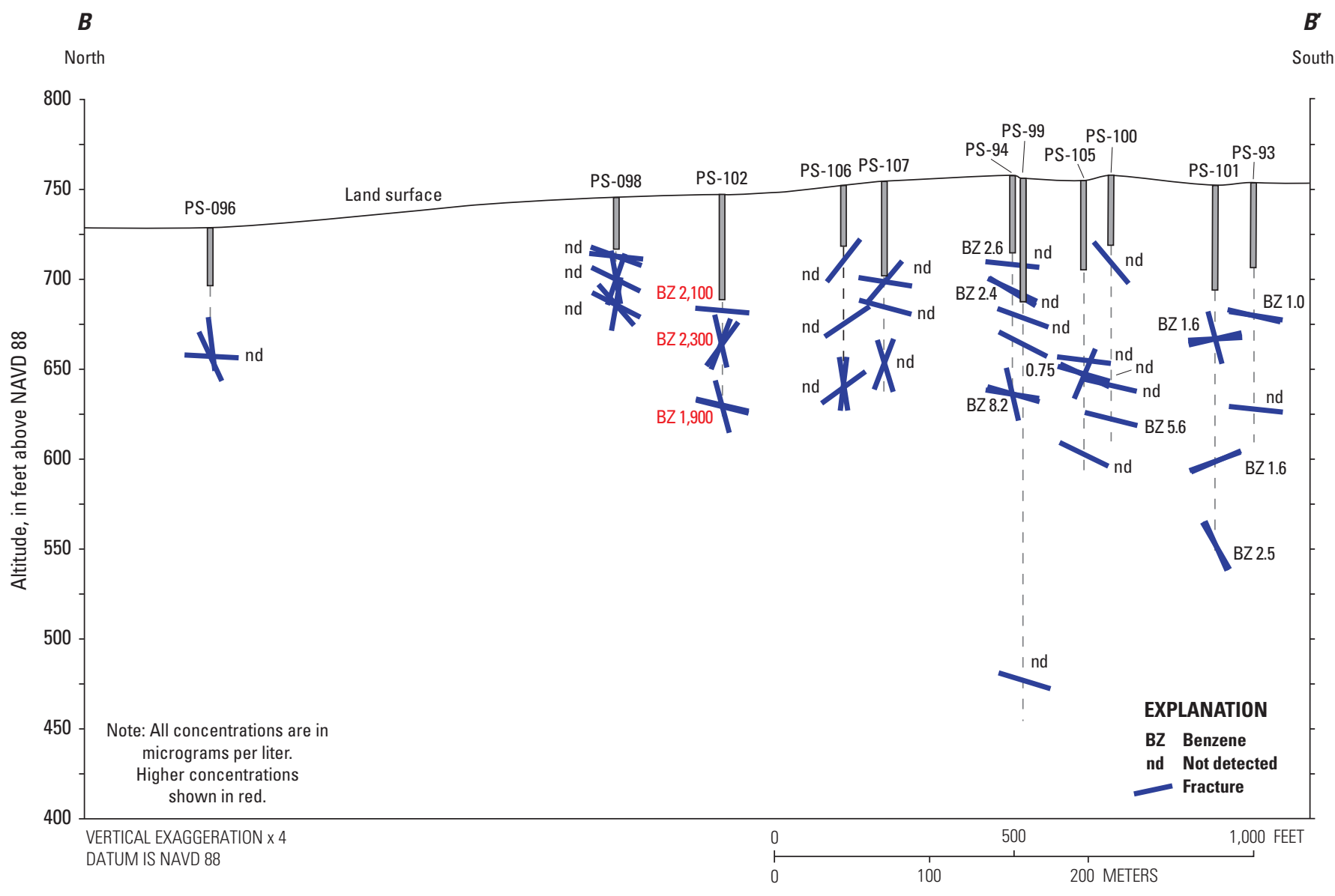

Figure 30. Schematic cross section $B-B$ ' showing depths to and orientations of borehole fractures and detected benzene concentrations from the passive diffusion bag samping during October 2011. Line of section shown on fig. 2. 


\section{References Cited}

aLt [Advanced Logic Technology], 2010, WellCad ${ }^{\circledR}$-The composite log package: Accessed February, 2013, at http://www.alt.lu/wellcad.htm.

Briggs, D.F., Gilbert, M.C., and Glover, L., III, 1978, Petrology and regional significance of the Roxboro metagranite, North Carolina: Geological Society of America Bulletin 1978, v. 89, p. 511-521.

Chapman, M.J., and Huffman, B.A., 2011, Geophysical logging data from the Mills Gap Road area near Asheville, North Carolina: U.S. Geological Survey Data Series 538, 49 p. + attachment. (Available only online at http://pubs.usgs.gov/ds/538/)

Chapman, M.J., Bolich, R.E., and Huffman, B.A., 2005, Hydrogeologic setting, ground-water flow, and groundwater quality at the Lake Wheeler Road research station, 2001-03, North Carolina Piedmont and Mountains Resource Evaluation Program: U.S. Geological Survey Scientific Investigations Report 2005-5166, 85 p.

Day-Lewis, F.D., Johnson, C.D., Paillet, F.L., and Halford, K.J., 2011, A computer program for flow-log analysis of single holes (FLASH): Ground Water, v. 49, no. 6. (Also available at http://dx.doi.org/10.1111/j.1745-6584.2011.00798.x)

Heath, R.C., 1980, Basic elements of ground-water hydrology with reference to conditions in North Carolina:

U.S. Geological Survey Open-File Report 80-44, 86 p.

Heath, R.C., 1983, Basic ground-water hydrology:

U.S. Geological Survey Water-Supply Paper 2220, 84 p.

Heath, R.C., 1984, Ground-water regions of the United States: U.S. Geological Survey Water-Supply Paper 2242, 78 p.

Heath, R.C., 1994, Ground-water recharge in North Carolina: Raleigh, North Carolina Department of Environment, Health, and Natural Resources, Groundwater Section, Open-File Report, 52 p.

Hibbard, J. P., Stoddard, E.F., Secor, D.T., and Dennis, A.J., 2002, The Carolina Zone: Overview of Neoproterozoic to Early Paleozoic peri-Goldwanan terranes along the eastern flank of the southern Appalachians: Earth Science Reviews, v. 57 , p. $299-339$.

Hibbard, J.P., van Staal, C.R., Rankin, D.W., and Williams, H., 2006, Lithotectonic map of the Appalachian Orogen, Canada-United States of America: Geological Survey of Canada, Map 2096A, scale 1: 1,500,000

North Carolina Geological Survey, 1985, Geologic map of North Carolina: Raleigh, North Carolina Geological Survey, scale 1:500,000.
Rockware, Inc., 2010, RockWorks earth science and GIS software: accessed September 24, 2010, at http://www.rockware.com/.

U.S. Environmental Protection Agency, 2009, GMH Electronics Site focused remedial investigation report: SESD project identification number 09-0016.

Vroblesky, D.A., 2001a, User's guide for polyethylene-based passive diffusion bag samplers to obtain volatile organic compound concentrations in wells-Part 1: deployment, recovery, data interpretation, and quality control and assurance: U.S. Geological Survey Water Resources Investigations Report 01-4060, $18 \mathrm{p}$.

Vroblesky, D.A., 2001b, User's guide for polyethylene-based passive diffusion bag samplers to obtain volatile organic compound concentrations in wells - Part 2: field tests: U.S. Geological Survey Water Resources Investigations Report 01-4061, $101 \mathrm{p}$. 


\section{Appendixes}

Appendixes 1-8 are available for download at $h t t p: / / p u b s . u s g s . g o v / d s / 762 /$ in the following formats:

1. Borehole geophysical logging field notes.

PDF

2. Heat-pulse flowmeter tool rinse volatile organic compound sample results MS Excel

3. Geologic structural measurements recorded near the GMH Electronics Superfund site MS Excel

4. Borehole geophysical logs showing depth of fracture zones, borehole flow, and percent contribution of fractures to flow in the well.................................................. PDF

5. Borehole geophysical image logs showing orientations of subsurface structural

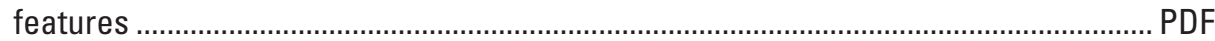

6. Rose diagrams showing dominant orientations of borehole structural features................. PDF

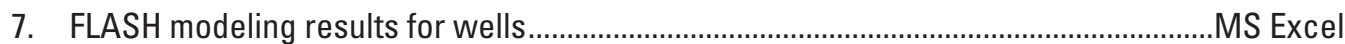

8. Analytical results of the passive diffusion bag sampling October 2011........................MS Excel 
For further information about this publication contact:

Director

U.S. Geological Survey

North Carolina Water Science Center

3916 Sunset Ridge Road

Raleigh, NC 27607

Or visit the North Carolina Water Science Center Web site at http://nc.water.usgs.gov/

Prepared by the Raleigh Publishing Service Center

A PDF version of this publication is available online at http://pubs.usgs.gov/ds/762/ 


\section{$\mathbb{R}$ \\ ณ}

愛

言

产

.

을

可.

응.

言

言

응

ว.

짛

홈

욜

E

ลิ.

हैं

亭

곡

m

胥

言

co

물

言

$\stackrel{\mathscr{P}}{*}$

록

ग्र

중

in

I 